\title{
Determination of Teaching Methods in Chemistry Education by the Analytic Hierarchy Process (AHP)
}

\author{
Mehmet YÜKSEL* \\ Yenimahalle Technical and Industrial Vocational High School, Ankara, \\ TURKEY
}

Abstract-In this study, the relative importance of the topics of the chemistry course for the 9th grade of the secondary education and their teaching methods for an effective chemistry course have been determined by the Analytic Hierarchy Process (AHP) technique. The AHP model of the research have been composed based on the topics in the chemistry course for the 9th grade and pair wise comparison matrix have been determined according to teachers' view. As a result of the study, relative importance of the topics of the chemistry course as per percentage are compounds $(47.8 \%$ ), chemical changes $(26.5 \%)$, chemical mixture $(13.6 \%)$, the development of chemistry $(6.3 \%)$, chemistry in our lives $(5.8 \%)$. The relative percentages of the teaching methods are narrative (32\%), demonstration (24.9\%), laboratory (18.9\%), question and answer (15.2\%), project work (9\%).

Keywords: chemistry, teaching methods, multi-criteria decision making, analytic hierarchy process

DOI No: http://dx.doi.org/10.12973/nefmed163

\section{Summary}

\section{Introduction}

The human ability to acquire an education has been determined to be associated with thinking and learning skills during history. Human beings better understood the planet and the universe in which they lived, and improved their quality of life, thanks to this ability to learn. The relationship between the phenomena of learning and education was also determined in

\footnotetext{
* Mehmet YÜKSEL, Dr., Yenimahalle Technical and Industrial Vocational High School, Ankara, TÜRKIYYE E-mail:m06yuksel@hotmail.com
} 
the history; this resulted in more studies about the content, method and assessment of the learning and education phenomena.

The relationship between the human will for comprehension, explanation, estimation and control with the field of chemistry was not considered independent of the education and learning phenomena, just as other social fields were not considered in terms of their relationship to chemistry.

Research studies have shown that efficient learning is related to various factors (Erdem, 2005; Kalem \& Fer, 2003; Seven \& Engin, 2008). Curriculums and methods of teaching were determined to be among the most basic factors affecting the success of the educational process (Eş \& Sarıkaya, 2010; Kurt \& Yıldırım, 2010; Özden, 2007;). According to the findings of the research studies conducted, secondary school curriculum and course book contents have deficiencies, at least in the case of the curriculums and semesters examined in these studies (Aydın, 2008; Aydın, 2010a; Aydın, 2010b; Ercan, 2011; Kayatürk, Geban \& Önal, 1995; Kurt \& Y1ldırım, 2010).

It is important to analyze the content of chemistry course books and curriculums with a detailed and objective approach in order to minimize problems with the functionality and applicability of the curriculums with regard to course books. In other words, it is necessary to determine the weights of secondary education curriculum units, as well as the subjects and chapters which compose these units, in the entire curriculum with a systematical and analytical approach. The teaching methods and techniques used are other factors that are just as important as curriculum in an efficient chemistry education. In the studies conducted, however, some problems were encountered (Aydın, 2008; Kayatürk et al., 1995; Küçük, Yetim, Saka \& Genel, 2002) in determining and using the suitable methods and techniques for chemistry education. For an efficient chemistry education, it is necessary to determine functional methods and techniques by considering the different contents of different subjects in the chemistry curriculum. According to the information given above, one of the main purposes of the current study is to determine the relative importance of the subjects comprising the 9th grade chemistry curriculum by means of the analytic hierarchy process (AHP). The second purpose of the study is to assess teaching methods and techniques on the basis of 9th grade chemistry lesson subjects' relative weights as calculated by the AHP technique. 9th grade chemistry lessons are considered to be the basic science lesson for all fields in secondary education. It has great significance, as it constitutes the basis for the efficacy of chemistry education after 9th grade, as stated also by Kayatürk et al. (1995). 
This is the main reason for including the 9th grade chemistry curriculum content in the study. This opinion is also stated in the 9th grade chemistry curriculum of the Ministry of National Education (MNE) (MEB, 2007). The main reason for using the AHP technique in the study is its structure, which is suitable for the solution of the study's question.

\section{Methodology}

In the current study, the AHP technique was used to assess the units composing the 9th grade chemistry course book, and the chapters which compose these units; relative weights of the subjects which compose these chapters; and teaching methods and techniques which can be possible used in the efficient chemistry education. The AHP technique is a multi-criteria decision-making technique primarily theorized by Saaty (1980). Firstly, a 5-level AHP model was prepared. The first phase of the study explains the purpose of the study; the second phase assesses the units composing the 9th grade chemistry lesson; the third phase assesses the chapters; the fourth phase assesses the subjects; and the fifth phase assesses teaching methods and techniques. Pair-wise matrixes were generated by taking the classification of factors in the AHP model into account (Saaty, 1980; Saaty, 1986). Local weights, global weights and consistency ratio were calculated by the solution of pair-wise matrixes. The data which acted as inputs for the solution of the research question are based on the opinion of a group of experts composed of teachers giving 9th grade chemistry courses in Ankara, in line with the estimations of the AHP.

\section{Results and Conclusion}

At the end of the research, it has been shown that the relative importance levels of 5 units, 16 chapters and 53 subjects composing the chemistry curriculum could be determined with the AHP technique. The relative importance of the units composing the chemistry lesson was found as follows: Compounds: $47.8 \%$, chemical changes: $26.5 \%$, mixtures: $13.6 \%$, the development of chemistry: $6.3 \%$ and chemistry in our life: $5.8 \%$. The relative importance of the subjects is necessary to resolve the problems encountered in the design, application and assessment of the program. The methods used while conducting the lessons included in the chemistry curriculum can also be analyzed in the current study. Accordingly, the weights of the teaching methods for the overall 9th grade chemistry curriculum were found as follows: 
expression technique: 32\%; display method: 24.9\%; laboratory: 18.9\%; question-answer method: $15.2 \%$ and projects: $9 \%$.

\section{Suggestions}

The method addressed in the current study is also applicable for the curriculums of other fields of science education. However, these results are limited to the scope of the present study. At the same time, it is not possible to generalize the study results for the entire 9th grade chemistry curriculum. A generalizable result can be obtained only by receiving data from teachers and experts who offer broad participation. In the AHP model that is recommended, the subjects were encouraged to be distinct and independent from each other. In another study, relative weights of the subjects can be determined with an approach that takes the relationship between the subjects included in the chemistry curriculum into consideration. 


\title{
Kimya Eğitiminde Öğretim Yöntemlerinin Analitik Hiyerarşi Prosesi (AHP) ile Belirlenmesi
}

\author{
Mehmet YÜKSEL ${ }^{\dagger}$ \\ Yenimahalle Teknik ve Endüstri Meslek Lisesi, Ankara,TÜRKİYE \\ Makale Gönderme Tarihi: 19.04.2012 \\ Makale Kabul Tarihi: 12.06 .2013
}

Özet-Bu çalışmada ortaöğretim programı 9.sınıf kimya dersi konularının göreli önemleri ve etkili bir kimya eğitiminde kullanılması olası öğretim yöntemleri Analitik Hiyerarşi Prosesi (AHP) tekniği ile belirlenmeye çalışılmıştır. Araştırmada 9. sınıf kimya dersi içeriğini oluşturan konular temelinde AHP modeli oluşturulmuş ve ikili karşılaştırma matrisleri öğretmen görüşlerine göre belirlenmiştir. Araştırma sonucunda kimya dersini oluşturan konuların kimya dersi içindeki göreli önemleri sırasıyla şöyle bulunmuştur: Bileşikler \% 47.8, kimyasal değişimler \% 26.5, karışımlar \% 13.6 ve kimyanın gelişimi için \% 6.3, hayatımızda kimya $\% 5.8$ 'dir. Kimya dersi genelinde konular temelinde öğretim yöntemlerinin ağıllıkları ise şöyledir: Anlatım \% 32, gösteri 24.9, laboratuvar \% 18.9, soru-cevap \% 15.2, proje çalışması $\%$ 9'dur.

Anahtar kelimeler: kimya, öğretim yöntemleri, çok ölçütlü karar verme, analitik hiyerarşi prosesi

\section{Giriş}

Tarihsel süreç içerisinde insanın edinmiş olduğu kazanımların, en genel anlamda ulaştığı uygarlık düzeyinin, insanın düşünme ve öğrenme yeteneği ile ilişkili olduğu görülmektedir. İnsan sahip olduğu bu temel yetenekler sayesinde yapmış olduğu keşif (discovery) ve icatlar (invention) ile tarihsel dönüşümler gerçekleştirilebilmiştir. İnsanın öğrenme yeteneği sayesinde ulaştığı bilgi birikimi, üzerinde yaşadığı gezegeni ve içerisinde bulunduğu evreni daha iyi anlamasına ve somut olarak yaşam kalitesini geliştirmesine olanak sağlamıştır. Bu süreçte, insanın öğrenme olgusuyla karşılaşılan güçlüklerin aşılabildiğini ve yaşam kalitesinin geliştirilebildiğinin farkına varmasıyla, öğrenme olgusuna daha da önem verilmiştir. Yine insanın tarihsel süreç içerisinde öğrenme olgusunun eğitim olgusuyla

\footnotetext{
${ }^{\dagger}$ Mehmet YÜKSEL, Dr., Yenimahalle Teknik ve Endüstri Meslek Lisesi, Ankara, TÜRKIYE

E-mail:m06yuksel@hotmail.com
} 
ilişkisinin saptanmış olması, eğitim ve öğrenme olgusunun içeriğine, yöntemine ve değerlendirilmesine yönelik araştırmaların yapılmasını yoğunlaştırmıştır.

İnsan, yaşamın ilişkili olduğu diğer alanlarda olduğu gibi kimya alanına ilişkin anlama, açıklama, öngörme ve kontrol etme istemini eğitim ve öğrenme olgularından bağımsız düşünmemiştir. $\mathrm{Bu}$, insanın kimya alanına ilişkin olgu ve olayların öğrenilmesine yönelik eğitimin niteliğinin ve öğretim yönteminin nasıl olması gerektiği sorunsalına yanıt aranan çalışmaların yapılmasına neden olmuştur. Yapılan araştırmalarda etkili bir öğrenmenin çeşitli öğelerle ilişkili olduğu (Erdem, 2005; Kalem ve Fer, 2003; Seven ve Engin, 2008) ve bu öğeler arasında öğretim programının içeriği ve öğretim yönteminin eğitimin başarısını belirleyen başlıca konular arasında olduğu saptanmıştır (Eş ve Sarıkaya, 2010; Kurt ve Yıldırım, 2010; Özden, 2007). Kimya alanına ilişkin bilgilerin kazandırılmasında özellikle kimya üst bilgilerinin kazandırılmasında fen ya da kimya eğitiminin verildiği ilk ve ortaöğretim programlarının içeriğinin temel ve biçimlendirici olması (Aydın, 2008; Aydın, 2010a; Kurt ve Yıldırım, 2010) kimya dersi programı içeriği ve tasarımının nasıl olması gerektiği sorunsalının araştırılmasını önemli kılmıştır.

Kimya dersi programlarının sonraki yıllarda verilecek kimya eğitimini biçimlendirmesi ve temel oluşturmasından kaynaklanan önemine ve Milli Eğitim Bakanlığının (MEB, 2007) son dönemde hazırlamış olduğu kimya öğretimi programlarında amaçlara yüklemiş olduğu stratejik niteliğe karşılık, programların uygulanabilirliği ve işlevselliği sorunlu olmuştur. Gözlenen bu durum geçmiş yıllarda değiştirilen programların uygulanmaya alınmasıyla çözümlenmeye çalışılmıştır. Nitekim Türkiye'de 1930-2007 yılları arasında 11 kez ortaöğretim kimya dersi öğretim programında değişiklik yapılmıştır. $\mathrm{Bu}$ program değişikliklerine karşılık uygulamaya alınan programların biri birinden belirgin farklılık oluşturucu temel özellikleri bulunmamıştır. Örneğin Türk Milli Eğitim Bakanlığının yürürlüğe koymuş olduğu 11 programın hiçbirinde "bilim ve teknikteki son değişiklikleri vurgulayan” bir içerikte olmadığı yapılan bir çalışmada ifade edilmektedir (Aydın, 2010b). Yine yazında yer alan araştırmaların (Aydın, 2008; Aydın, 2010a; Özden, 2007; Kurt ve Yıldırım, 2010) bulgularına göre, MEB Talim ve Terbiye Kurulu Başkanlığı tarafından önerilen ortaöğretim programlarının içeriklerinde ve uygulanmasından kaynaklanan çok sayıda eksiklik, yetersizlik ve güçlükle karşılaşıldı̆̆ı saptanmıştır.

Öğretim programının, kimya öğretiminin verimli bir şekilde yürütülmesinde önemli bileşenlerinden biri olduğunu ifade eden Özden (2007), yapmış olduğu araştırmada öğretmenlerin \% 65'i liselerde uygulanan kimya öğretimi programının kimya öğretimi 
bakımından yeterli bulmadıklarını saptamıştır. Aynı araştırmada öğretmenlerin \% 58'i kimya ders saatinin müfredatta belirtilen konuların anlatılması için yetersiz olduğunu ve yine öğretmenlerin \% 70’i kimya dersi müfredatının yeni gelişmeleri kapsamadığını ifade etmişlerdir. Yakın bir tarihte ortaöğretim 9. sınıf kimya dersi öğretim programı kapsamında yapılan bir başka çalışmada (Kurt ve Yıldırım, 2010), programda önerilen sürelerin yeterli olmadığı, programın içeriğinin uygulamadaki ders yükü ile karşılanamadığı, çok sayıda konu başlığının bulunduğu, hangi konuların ve hangi ayrıntıda verileceğinin bilinmediği öğretmenler tarafindan ifade edilmiştir. 9. sınıf kimya dersinin lise eğitiminde temel ders olması ve sonraki yıllarda verilecek kimya derslerine temel oluşturucu özelliği (Kayatürk, Geban ve Önal, 1995) düşünüldüğünde, Kurt ve Yıldırım'ın (2010) çalışmasında saptamış olduğu sorunların kimya eğitimi açısından ciddi sayılabilecek sonuçlarının olduğu söylenebilir. Yine aynı araştırmada önerilen ders kitabının farklı türdeki okulların gereksinimine yanıt veremediği gibi, ileride fen bilimleri eğitimine devam edecek öğrencilere uygun içerikte olmadığı söylenmiştir. Kimya ders kitabının daha çok meslek liselerindeki öğrencilere uygun olduğu, ders kitabındaki konuların veriliş sırasında yanlışlıkların bulunduğu, programda yer alan kavramların ne düzey ve ayrıntıda anlatılacağına yönelik sınırların belirli olmadığı, öğretmenlerin karşılaştıkları sorunlar arasında yer almıştır. Öte yandan ders kitabında yer alan birçok konunun izleyen programlarda aynı başlıklarla yer aldığını ve dolayısıyla hangi sınıfta, konuların hangi içerikte ve düzeyde verileceğinin öğretmenler tarafından bilinmediği saptanmıştır. Program konusunda 9.sınıf kimya I ders kitabının içerik yönünden değerlendirilmesine ilişkin yapılmış bir başka araştırmada da (Aydın, 2010a) benzer sorunlarla karşılaşılmıştır. Araştırmada Kimya I ders kitabında öğrenci seviyesinin dikkate alınmadığı, programa uygunluk seviyesine önem verildiği, öğrencilerin algılamaları, kavram öğretimi, verilen örnekler, bilginin gerekliliği ve öğrencilerdeki davranış değişikliği konularına yeterli düzeyde önem verilmediği araştırma sonucunda görülmüştür.

MEB Talim ve Terbiye Kurulu Başkanlığı tarafından 2007 yılında yürürlüğe konulan ortaöğretim 9. sınıf kimya dersi programında karşılaşılan sorunlara geçmiş yıllardaki programlarda da rastlanılmıştır. Nitekim Kayatürk vd.'nin (1995) lise müfredatındaki fen bilimleri ve kimya I, II, III derslerini konu edinen araştırmada; fen bilimleri I ve II ders programlarının içeriğinin sorunlu olduğu, programda tutarsızlıkların bulunduğunu, programın diğer temel fen bilimleri konularıyla bütünlük oluşturmadığı saptanmıştır. Programda fen ve kimya derslerinin içermiş olduğu deney sayısının yetersizliğinin yanı sıra, uygulamada araştırma kapsamındaki okulların yarısında deney yapılmadığı saptanmıştır. Türkiye'de 1992 yılından itibaren uygulanan kimya müfredatlarının öğretmen görüşleri temelinde 
değerlendirilmesine yönelik bir araştırmada ise (Aydın, 2008); öğretmenlerin \% 70’i kimya müfredatlarında uygulamaya yönelik eksiklik ve yetersizlikler bulunduğunu, yine öğretmenlerin \% 54'ü programın öğrencilerin öğrendikleri kavramları günlük yaşantılarına uygulamalarıyla uyumlu bulunmadığını belirtmişlerdir. Araştırma kapsamındaki öğretmenlerin yalnızca \% 46’sı programın açık, anlaşı1ır olduğunu belirtmişılerdir. Programın süresini yeterli bulan öğretmenlerin oranı ise \% 38 bulunmuştur. Bir başka çalışmada (Ercan, 2011) öğretmenlerin \% 33’ü öğretim programında fazla ya da gereksiz konuların olduğunu ifade etmişlerdir. Örneğin 9. sınıf kimya dersinde simyadan kimyaya, polimerleşme, organik bileşikler ve biyolojik sistemler konularının gereksiz bir şekilde ayrıntılandırılmış olduğu ve hayatımızda kimya ünitesi için öngörülen ders saatinin fazla olduğu belirtilmiştir. Öğretim programları ile ders kitaplarının uyumlu olmadığı ve ders saatlerinin yeterli olmadığ1 öğretmenler tarafından ifade edilmiştir. Yapılan araştırmaların bulguları ortaöğretim program ve ders kitaplarının, en azında araştırmaların yapıldığı programlar ve dönemler için sistematik bir dizi eksiklik ve yetersizlik içerdiğini göstermektedir. Program ve ders kitaplarının işlevselliği ve uygulanabilirliğindeki sorunların en aza indirgenmesi kimya ders program ve kitaplarının içeriğinin nesnel ve ayrıntılı bir yaklaşımla belirlenmesini önemli kılmaktadır. Bir diğer deyişle ortaöğretim programında yer alan ünitelerin, üniteleri oluşturan konuların ve alt konuların program bütünü içerisindeki ağırlıklarının düzeyinin sistematik ve analitik bir yaklaşımla belirlenmesini gerektirmektedir.

Etkili bir kimya eğitiminde program içeriği kadar önemli olan bir diğer faktör ise eğitimde kullanılan öğretim yöntem ve teknikleridir. Nitekim yapılan araştırmalarda kimya eğitiminin amaçlarının gerçekleştirilmesi ve kimya eğitiminin doğasından kaynaklanan öğrenme güçlügüünün (Demircioğlu, Demircioğlu, Ayas, 2006; Driel, Bulte ve Verloop, 2008; Küçük, Yetim, Saka ve Genel, 2002; Pekdağ, 2010) aşılmasında uygun öğretim yöntem ve tekniklerinin rolü önemli bulunmuştur. Bu düşünceden hareketle geliştirilmiş olan çeşitli öğretim yöntem ve tekniklerinin olduğu ve uygulamada kullanıldığı ya da etkililiğinin araştırmalara konu edildiği çalışmalar yapılmıştır (Aydoğdu, 2003; Bolte, 2008; Çevik ve Yücel, 2009; Demircioğlu vd., 2006; Feyzioğlu 2009; Gerengi, 2009; Küçük vd., 2002; Lang, Wong, ve Fraser, 2005; Morgil, Y1lmaz ve Yavuz, 2002; Morgil, Erdem ve Y1lmaz, 2003; Tezcan ve Günay, 2006;).

Türk eğitim sisteminde öğretim programları konusunda olduğu gibi eğitim sürecinin ve işleyişinin de sorunlu olduğu söylenebilir. Kimya eğitiminde öğretim yöntem ve tekniklerinin işlevselliği ve mevcut kullanım durumuna yönelik 1995 yılında yapılan bir araştırmada 
(Kayatürk vd., 1995), kimya eğitimi sürecinde, derslerde ağırlıklı olarak anlatım yöntemlerinin kullanıldığı, araştırma niteliğindeki yöntemlerin ise az sayıda öğretmen tarafından kullanıldığı saptanmıştır. 2002 yılında yapılan bir başka çalışmada da (Küçük vd., 2002) benzer sorunlarla karşılaşılmıştır. Araştırmada kimya eğitimi sürecinde öğretmen merkezli yöntemlerin uygulandığı ve daha çok yazı tahtasının eğitim aracı olarak kullanıldı̆̆ı, öğretmenlerin büyük çoğunluğunun (\% 60-71) anlatım yöntemini kullandıkları, eğitim sürecinde alternatif öğretim yöntemlerinin ise yoğunluklu kullanılmadığı saptanmıştır. Bununla birlikte araştırmada kimya eğitiminde öğretmenlerin ders programı ve konularının amaçlarına uygun öğretim yöntem ve tekniklerinin kullanılmasına ilişkin bilgilere gereksinim duydukları ve buna ilişkin yeterli bir bilgilendirmenin yapılmadığı belirtilmiştir. 2008 yılında yapılan bir başka araştırmada da (Aydın, 2008) Türk eğitim sisteminde aynı ya da benzer sorunların devam ettiği görülmüştür. Yapılan araştırmada program ve konuların amaçlarına uygun öğretim yöntem ve tekniklerine ilişkin bilgilendirmenin yapılmadığı öğretmenler tarafından ifade edilmiştir. Yukarıda belirtilen araştırmaların bulguları kimya eğitimi sürecinde uygun ve işlevsel öğretim yöntem ve tekniklerinin belirlenmesi ve seçiminin önemli bir sorunsal olduğunu göstermektedir.

Bilim dallarının kendine özgü nitelik, karmaşıklık ve ulaşılan bilgi birikimindeki farklılıklara koşut olarak eğitim sürecinde kullanılan eğitim yöntem ve teknikleri de farklılık gösterebilmektedir. Ancak bu farklılıklarla bilim dalının kendi içerisinde de karşılaşılabilmektedir. Bir bilim dalının içermiş olduğu konuların, kavramların tamamınım aynı eğitim yöntem ve teknikleriyle öğretimi olası değildir. Bu özellik kimya bilimi için de söz konusudur. Bir diğer deyişle bütün kimya konularının aynı yöntem ve teknikle öğretilmesi olası değildir. Kimya eğitiminde kullanılan öğretim yöntem ve tekniklerinin biri birine göre kimya eğitiminin içeriğini oluşturan konuların kavranması açısından bazı eksiklikleri, yetersizlikleri ya da üstünlükleri ve dolayısıyla farklılıkları olasıdır. Bununla birlikte konuların içeriğine ve özelliklerine göre kullanılacak öğretim yöntem ve teknikleri farklılık gösterebilecektir. Karşılaşılan bu sorunsal kimya eğitimi alanında önerilen ya da kullanılan çok sayıda yöntem ve tekniğin etkililiği konusundaki çalışmaların (Demircioğlu vd., 2006; Küçük vd., 2002) yapılmasına neden olmuştur. Ancak yazında ortaöğretim kimya dersi programlarının içermiş olduğu konuların hangi teknik ve yöntemlerle verilmesinin daha etkili bir öğrenmeye olanak sağlayacağı sorunsalını bütüncül bir yaklaşımla karşılaştırmalı olarak irdeleyen çalışmaya yazında rastlanılmamıştır. Öte yandan geçmiş yıllarda MEB tarafından hazırlanan programlarda bu konuda bir bilgilendirme yapılmadığı yapılan araştırmaların bulgularında görülmektedir (Aydın, 2008; Küçük vd., 2002). Yürürlükte olan 
ortaöğretim 9. sınıf kimya dersi programında da (MEB, 2007) kimya ders kitabının (Dursun, Gülbay, Çetin ve Tek, 2011) içeriğini oluşturan konuların öğrenciler tarafindan kavranması ve programda belirtilen amaçlara ulaşılması için eğitimin hangi öğretim yöntem ve teknikleriyle verilmesine ilişkin bir bilgilendirme yapılmamıştır. Ders kitabının içeriğini oluşturan konuların tamamının tek ve aynı öğretim yöntem ve tekniğiyle öğretilebileceğini söylemek ise olası değildir. Programın içermiş olduğu konuların işlenişinde kullanılacak öğretim yöntem ve tekniklerin konuların öğrenciler tarafından kavranabilmesine olanak sağlayacak işlevsellikte olması önemlidir. Ders kitabının içermiş olduğu konuların doğasından kaynaklanan farklılık değişik öğretim yöntem ve tekniklerin kullanılmasını gerektirebilmektedir. Ancak 9. sınıf kimya dersi programının içeriğinde yer alan konuların çok sayıda ve farklı nitelikte olduğu bilinmektedir. Kimya dersi programının içermiş olduğu konu içerik farklılığını dikkate alarak kimya öğretiminde işlevsel hangi yöntem ve tekniklerin kullanılabileceğinin belirlenmesi verilen kimya eğitiminin etkililiği açısından çözülmesi gereken çok boyutlu bir sorundur. $\mathrm{Bu}$ durum kimya eğitimi sürecinde işlevsel olabilecek uygun öğretim yöntem ve tekniklerin seçimi sorununun çok boyutlu yaklaşım ve tekniklerle incelenmesini gerektirmektedir. Ancak yazın incelemesinde öğretim yöntem ve tekniklerinin seçimini çok ölçütlü karar verme teknikleriyle belirleyen çalışmalara rastlanılmamıştır. Yukarıdaki bilgilerin 1şığında bu çalışmanın başlıca iki temel amacı bulunmaktadır:

1. Ortaöğretim 9. sınıf kimya dersi programı içeriğini oluşturan konuların kimya dersi içerisindeki göreli önemlerini (ağırlıklarını) Analitik Hiyerarşi Prosesi (AHP) ile saptamak

2. AHP tekniğiyle hesaplanan 9. sınıf kimya dersi konuların göreli ağırlıkları temelinde kimya dersini oluşturan konuların öğretiminde kullanılabilecek öğretim yöntem ve tekniklerini belirlemektir.

Çalışmanın kapsamını 9. sınıf kimya dersinin oluşturmasının temel nedeni, Kayatürk vd.'nin (1995) ifade etmiş olduğu gibi, 9. sınıf kimya dersinin hem ortaöğretimde bütün alanlar için temel bir fen dersi olması ve aynı zamanda 9. sınıf sonrası kimya eğitimine temel oluşturmasından kaynaklanan önemidir. Çalışmada AHP tekniğinin kullanılmasının temel gerekçesi ise araştırmanın amaçlarının doğasından kaynaklanmaktadır. Nitekim ortaöğretim 9. sınıf kimya dersi içeriğinde beş ünite, ünitelerin kapsamış olduğu 16 bölüm ve bölümlerin içermiş olduğu 53 konu bulunmaktadır. Kimya dersinin içermiş olduğu konuların bölüm, ünite ve bütün kimya dersi içerisinde nesnel bir şeklide ağırlıklandırılması, ancak bu bütünlük ve ilişki örüntüsünü dikkate alan bir yaklaşımla değerlendirilmesiyle olasıdır. Öğretim yöntemlerinde de benzer bir durum söz konusudur. Yukarıda ifade edildiği gibi program 
içeriğini oluşturan çok sayıda konu bulunduğu gibi her bir konunun farklı öğretim yöntemleriyle verilmesi olası bulunmaktadır. Bununla birlikte bir konunun öğretiminde aynı zamanda birden fazla öğretim yöntem ve tekniğinin kullanılabilmesi olasıdır. Öğretim yöntem ve tekniğinin belirlenmesi konusunun da çok boyutlu bir özelliği bulunmaktadır. Yazın incelemesinde doğası çok boyutlu olan sorunsalların çözümünde AHP tekniğinin (Saaty, 1980) işlevsel olduğu görülmüştür. Bu nedenle bu araştırmada AHP tekniği kullanılmıştır.

Yazında az sayıda da olsa çok ölçütlü karar verme tekniklerini eğitim ve öğretim sorunsallarının çözümünde kullanan çalışmalar (Gültaş, 2007; Yetim, 2004) bulunmaktadır. Bu çalışmalardan ilki Yetim'in (2004) tek değişkenli reel değerli fonksiyonlarda türev kavramına etki eden bazı matematik kavramlarını, çok ölçütlü karar verme tekniklerinden biri olan AHP tekniği ile bağıntı, fonksiyon, limit ve süreklilik faktörlerinin önceliklerinin belirlenmesi konusundadır. Bir diğer çalışma ise (Gültaş, 2007) endüstri mühendisliği eğitiminde; doğrusal programlama, doğrusal olmayan programlama, tamsayılı programlama, stok/envanter modelleme, tahmin modelleri, oyun teorisi, karar teorisi, dinamik programlama, stokastik programlama gibi yöneylem araştırması konularına göre matematik ders içeriklerini üniversite öğretim elemanlarının görüşleri temelinde bulanık AHP tekniği ile belirlenmesini amaçlamıştır. $\mathrm{Bu}$ araştırmaların bulguları eğitim alanındaki çok boyutlu nitelikte olan sorunsalların çözümünün yine çok ölçütlü analitik yaklaşımlarla çözümlenmesinin daha nesnel sonuçlara ulaşılmasına olanak sağladığını göstermiştir.

Bu çalışmanın diğer kısımları şöyle tasarlanmıştır: İzleyen kısımda çalışmanın yöntemi ve çalışmada kullanılan Analitik Hiyerarşi Prosesi (AHP) tekniği açıklanmıştır. Bulgular kısmında ders kitabının içeriğinde yer alan konuların göreli ağırlıkları ve bu ağırlıklar temelinde belirlenmiş olan öğretim yöntem ve teknikleri verilmiştir. Tartışma ve öneriler kısmında ise ulaşılan sonuçlar irdelenmiş düşünülen öneriler sunulmuştur.

\section{Yöntem}

Bu çalışmada, giriş bölümünde belirtildiği gibi 9. sınıf kimya dersi programı içeriğini oluşturan ünite, bölüm ve konuların göreli ağırlıkları ve bu ağırlıklar temelinde etkili bir kimya eğitimi için kullanılması olası öğretim yöntem ve teknikleri AHP tekniği ile belirlenmeye çalışılmıştır. Çalışmanın bu iki temel amacının AHP tekniğiyle çözümü için öncelikle AHP modeli oluşturulmuştur. AHP modeli beş seviyeden oluşmaktadır (Çizim 1): Modelin birinci aşamasında amaç, ikinci aşamasında 9. sınıf kimya dersini oluşturan üniteler, üçüncü aşamasında bölümler ve dördüncü aşamasında konular ve beşinci aşamasında ise öğretim yöntem ve teknikleri yer almaktadır. Modeldeki gösterimlerin karş1lıkları üçüncü 
bölümde Tablo 3 ila Tablo 24'te bulunmaktadır. AHP modelindeki sınıflandırmada MEB'nın 9. sınıflarda okutulmak üzere önermiş olduğu ders kitabı esas alınmıştır. Modelin beşinci seviyesinde yer alan öğretim teknikleri ise ilgili yazın temel alınarak belirlenmiştir. Yazın incelemesinde çok sayıda öğretim yöntem ve tekniğinin eğitim alanında kullanıldı̆̆ önerildiği görülmüştür (Aydoğdu, 2003; Bolte, 2008; Çevik ve Yücel, 2009; Demircioğlu vd., 2006; Feyzioğlu 2009; Gerengi, 2009; Küçük vd., 2002; Lang vd., 2005; Morgil vd., 2003; Tezcan ve Günay, 2006). Ancak bu çalışmada kimya eğitiminde yoğunlukla kullanılan düz anlatım, laboratuvar, gösteri, soru-cevap ve proje yöntem ve teknikleri araştırma kapsamına alınmıştır.

Araştırmada kullanılan AHP tekniği Saaty (1980) tarafından geliştirilmiş çok ölçütlü karar verme tekniğidir. AHP tekniğinde öncelikle, araştırmanın sorunsalını yansıtan model oluşturulmaktadır. Modelde araştırmanın sorunsalı en üst seviyeden (amaç) en alt seviyeye ve alternatiflere kadar hiyerarşik olarak ifade edilmektedir. Böylece sorunsalı oluşturan bütün ölçütlerin (öğelerin) AHP modelinde yer alması sağlanmaktadır. AHP modelindeki öğelerin gruplandırılması esas alınarak ikili karşılaştırma (pair-wise) matrisleri oluşturulmaktadır (Saaty, 1980; 1986). AHP'de $i$. öğe ile $j$. öğenin ikili karşılaştırılması $a_{i j}$ ile ve $j$. öğe ile $i$. öğenin karşılaştırılması ise $a_{j i}$ ile gösterilmektedir. AHP tekniğinde $a_{j i}=1 / a_{i j}$ eşitliği ile tanımlanmaktadır. AHP modelinde yer alan öğelerin ikili karşılaştırmaları bulundukları gruplara göre yapılmakta ve ikili karşılaştırmaların sayısal değerlere dönüştürülmesi yine Saaty’nin (1980) önermiş olduğu ölçek (Tablo 1) ile yapılmaktadır. AHP modelinde yer alan öğelerin gruplandırılmasına göre oluşturulan matrisler $n x n$ boyutunda kare matrislerdir. $\mathrm{Bu}$ matrislerde $n(n-1) / 2$ kadar ikili karşılaştırma yapılır. 


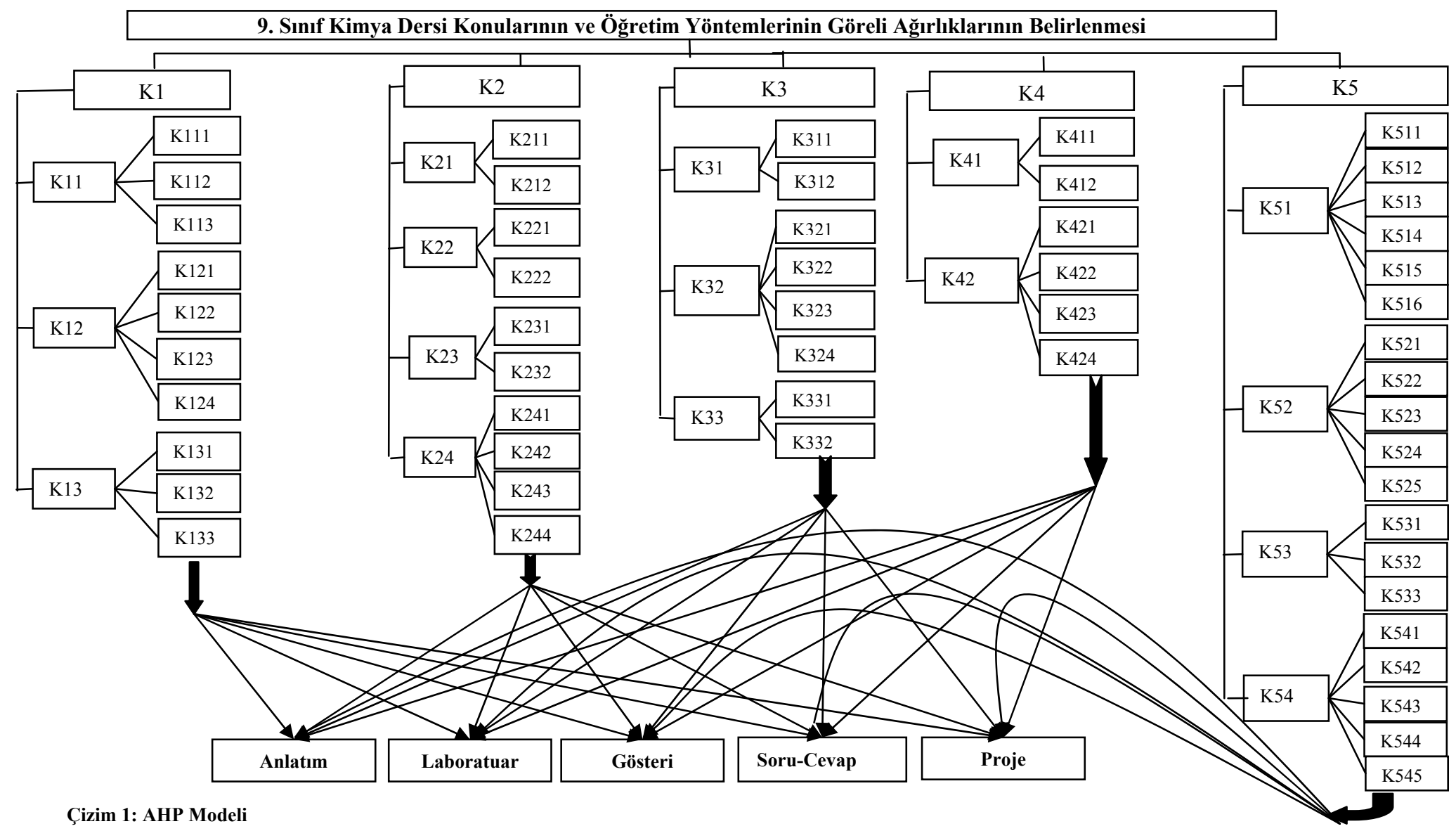


Tablo 1 AHP Ölçeğinde Önem Değerleri ve Tanımları (Saaty, 1980).

\begin{tabular}{cll}
\hline $\mathrm{a}_{\mathrm{ij}}$ & Tanım & Açıklama \\
\hline 1 & Eşit düzeyde önemli & İki ölçütün eşit derecede öneme sahip olması durumu \\
\hline 3 & Biraz önemli & Bir ölçütün diğerine karşı biraz üstün olması durumu \\
\hline 5 & Kuvvetli derecede önemli & Bir ölçütün diğerine karşı oldukça üstün olması durumu \\
\hline 7 & Çok kuvvetli derecede önemli & Bir ölçütün diğerine göre üstün kabul edilmesi \\
\hline 9 & Kesin önemli & $\begin{array}{l}\text { Bir ölçütün diğerinden üstün olduğunu gösteren kanıt çok } \\
\text { büyük güvenilirliğe sahip ise }\end{array}$ \\
\hline $2,4,6,8$ & Ara değerler & İki ardışı yargı arasında karar verme durumunda \\
\hline
\end{tabular}

AHP' de ikili karşılaştırmaların sayısal değerlere dönüştürülmesi sonucunda oluşturulan nxn boyutlu matrislerin gösterimi ise şöyledir (Saaty, 1980):

$$
A=\left[\begin{array}{cccc}
a_{11} & a_{12} & \cdot & a_{1 n} \\
a_{21} & a_{22} & \cdot & a_{2 n} \\
\cdot & \cdot & \cdot & \cdot \\
a_{n 1} & \cdot & \cdot & a_{m n}
\end{array}\right]=\left[\begin{array}{cccc}
1 & a_{12} & \cdot & a_{1 n} \\
1 / a_{12} & 1 & \cdot & a_{2 n} \\
\cdot & \cdot & 1 & \cdot \\
1 / a_{1 n} & 1 / a_{2 n} & \cdot & 1
\end{array}\right]
$$

AHP tekniğinde öncelik vektörü $\left(A-\lambda_{\max } I\right) W=0$ eşitliğinin çözümüyle sağlanmaktadır. $\mathrm{Bu}$ eşitlikte $A$ ikili karşılaştırma matrisini, $W$ özvektör ve $\lambda_{\max } A$ matrisinin en büyük özdeğeridir. AHP' de yapılan ikili karşılaştırmaların tutarlı olması gerekmektedir (Saaty, 1980; Saaty, 1991). Tutarlılık, ikili karşılaştırma matrislerinin tutarsızlık oranlarının hesaplanmasıyla belirlenmektedir. İkili karşılaştırma matrislerinin tutarsızlık oranı(T.O.), tutarlılık indeksi (T.I.) ve rassal indeks (R.İ.) değerlerine göre belirlenmektedir. Bunu için öncelikle ikili karşılaştırma matrisinin özdeğeri $\left(\lambda_{\max }\right)$ kullanılarak tutarlılık indeksi(T.İ) hesaplanmaktadır. Tutarlılık indeksi şu eşitlikle bulunmaktadır: T.İ $=\left(\lambda_{\max }-n\right) /(n-1) . B u$ eşitlikteki $n$ matrisin boyutunu göstermektedir. Rassal indeks ise matrisin boyutuna (Tablo 2) göre belirlenmektedir. Tutarsızlık oranı ise T.O = Tİ / Rİ eşitliğiyle hesaplanmaktadır. Buna göre belirlenen tutarsızlık oranının değeri matrisin boyutuna göre değişmekle birlikte genelde 0.10'dan küçük ise yapılan ikili karşılaştırmalar tutarlı kabul edilmektedir (Saaty, 1994). Tutarsızlık olması durumunda ise ikili karşılaştırmalar yinelenmektedir. İkili karşılaştırmaların yapılması, ağırlıkların (önem) belirlenmesi ve tutarlılık oranlarının hesaplanması AHP modelinde yer alan bütün hiyerarşik seviyelerdeki gruplandırmalar için yapılmaktadır. Bu çalışmada ikili karşılaştırma matrislerinin çözümü ve tutarsızlık oranının (T.O.) hesaplanması Expert Choice (2000) programı ile yapılmıştır. 
Tablo 2 Rassal İndeks Değerleri (Rİ) (Saaty, 1980)

\begin{tabular}{lccccccccc}
\hline Matrisin Boyutu $(n)$ & $\mathbf{1}$ & $\mathbf{2}$ & $\mathbf{3}$ & $\mathbf{4}$ & $\mathbf{5}$ & $\mathbf{6}$ & $\mathbf{7}$ & $\mathbf{8}$ & $\mathbf{9}$ \\
\hline Rastgele İndeks Değeri $(R \dot{I})$ & 0 & 0 & 0.58 & 0.9 & 1.12 & 1.24 & 1.32 & 1.41 & 1.45 \\
\hline
\end{tabular}

Bu çalışmada konuların göreli ağırlıklarının ve öğretim yöntemlerinin ağırlıklarının belirlenmesi için oluşturulan matrislerdeki (Tablo 3-24) ikili karşılaştırmalar $\left(a_{i j}\right)$, bir uzman grubun görüşü temelinde, Saaty'nin (1980) önermiş olduğu 1-9 ölçeğine göre (Tablo 1) yapılmıştır. Uzman grup 9. sınıf kimya dersi veren başöğretmen, uzman öğretmen ve öğretmenden oluşmuştur.

\section{Bulgular}

Çalışmanın bulguları üç başlık altında incelenmiştir: Birinci kısımda AHP modelinde yer alan kimya dersi konularının göreli ağırlıkları verilmiştir. Göreli ağırlıklar her bir konunun kimya dersi kapsamında diğer konulara göre öneminin ne düzeyde olduğunu belirtmektedir. İkinci kısımda belirlenen bu ağırlıklar temelinde konuların öğretiminde kullanılabilmesi olası yöntem ve tekniklerin belirlenmesine yönelik bulgular, üçüncü kısımda ise çalışmanın bulgularına ilişkin duyarlılık analizi sonuçları verilmiştir.

\section{Ünitelerin, Bölümlerin ve Konuların Göreli A ğırlıkları}

Araştırmada öncelikle AHP modelinin (Çizim 1) ikinci seviyesinde yer alan ünitelerin kimya dersi bütünü içerisindeki göreli önemleri (yerel ağırlıkları) belirlenmiştir. Ünitelere ilişkin yerel ağırlıklar her bir ünitenin 9. sınıf kimya dersi programı içerisinde ne düzeyde önemli olduğunu göstermektedir. Bir diğer deyişle her bir ünitenin yerel ağırlığı, hem 9. sınıf kimya bilgisinin öğrenciye kazandırılması ve konularının kavranmasında hem de sonraki yıllarda lise ya da lise sonrası kimya derslerinin kavranmasına ne düzeyde etkisinin olduğunu ifade etmektedir. Bu düşünce temelinde oluşturulan ikili karşılaştırma matrisi ve hesaplanan yerel ağırlıklar Tablo 3'te verilmiştir. Buna göre kimya dersi içeriğini oluşturan üniteler arasında bileşikler diğer ünitelere göre daha ağırlıklı bulunmuştur. Bileşikler ünitesini sırasıyla kimyasal değişimler, karışımlar, kimyanın gelişimi ve hayatımızda kimya konusu izlemektedir. Bu çalışmada yöntem kısmında da ifade edilmiş olduğu gibi araştırmada yapılan bütün ikili karşılaştırmaların tutarlı olup olmadığı hesaplanmıştır. Araştırmada yapılan bütün ikili karşılaştırmaların AHP tekniği varsayımlarına göre tutarlı olduğu saptanmıştır. Her bir ikili karşılaştırma matrisinin tutarsızlık oranı (T.O) matrisin son satırında verilmiştir. Örneğin 
ünitelere ilişkin ikili karşılaştırmaların (Tablo 3) tutarsızlık oranı 0.04 bulunmuştur. Bu değer AHP varsayımlarına göre ikili karşılaştırma matrisinin tutarlı olduğunu göstermektedir.

Tablo 3 Kimya Dersi İçeriğini Oluşturan Ünitelere İlişkin İkili Karşılaştırma Matrisi

\begin{tabular}{lcccccc}
\hline & K1 & K2 & K3 & K4 & K5 & Yerel Ă̆ırlıklar \\
\hline Kimyanın Gelişimi $($ K1) & 1 & $1 / 5$ & $1 / 4$ & $1 / 3$ & 1 & 0.0633 \\
\hline Bileşikler $($ K2) & & 1 & 3 & 4 & 6 & 0.4780 \\
\hline Kimyasal Değişimler $($ K3) & & & 1 & 3 & 5 & 0.2649 \\
\hline Karşımlar $($ K4) & & & & 1 & 3 & 0.1362 \\
\hline Hayatımızda Kimya(K5) & & & & 1 & 0.0576 \\
\hline T.O: 0.04 & & & & & \\
\hline
\end{tabular}

Kimyanın gelişimi Ünitesini Oluşturan Bölüm ve Konulara İlişkin İkili Karşılaştırma Matrisleri

9. sınıf kimya dersinin kimyanın gelişimi ünitesini oluşturan bölümlerin ünite içerisindeki göreli ağırlıkları hesaplanmıştır (Tablo 4). Kimyanın temel kanunları ile kimyasal bağ kavramının gelişiminin eşit ağırlıkta olduğu, simyadan kimyaya bölümünün ise ağırlığının düşük olduğu saptanmıştır.

Tablo 4 Kimyanın Gelişimi Ünitesine İlişkin Bölümlerin İkili Karşılaştırma Matrisi

\begin{tabular}{lcccc}
\hline & K11 & K12 & K13 & Yerel Ă̆ırlıklar \\
\hline Simyadan Kimyaya (K11) & 1 & $1 / 7$ & $1 / 7$ & 0.0667 \\
\hline Kimyanın Temel Kanunları (K12) & & 1 & 1 & 0.4667 \\
\hline Kimyasal Bă̆ Kavramının Gelişimi (K13) & & & 1 & 0.4667 \\
\hline T.O: 0.00 & & & & \\
\hline
\end{tabular}

Simyadan kimyaya bölümünü oluşturan üç konuya ilişkin ikili karşılaştırma matrisi incelendiğinde (Tablo 5), eski çağlarda keşfedilen maddeler ve simya konularının eşit önemde bir ağırlığa sahip olduğu, element kavramının tarihsel gelişimi konusunun ağırlığının ise diğer iki konunun ağırlığından daha yüksek olduğu saptanmıştır.

Tablo 5 Simyadan Kimyaya Bölümüne İlişkin Konuların İkili Karşılaştırma Matrisi

\begin{tabular}{lcccc}
\hline & K111 & K112 & K113 & Yerel Ă̆ırlıklar \\
\hline Eski Çă̆larda Keşfedilen Maddeler (K111) & 1 & 1 & $1 / 3$ & 0.200 \\
\hline Simya (K112) & & 1 & $1 / 3$ & 0.200 \\
\hline Element Kavramının Tarihsel Gelişimi (K113) & & 1 & 0.600 \\
\hline T.O:0.00 & \multicolumn{5}{l}{} \\
\hline
\end{tabular}

Kimyanın gelişiminin içerdiği bir diğer bölüm olan kimyanın temel kanunları bölümüne ilişkin ikili karşılaştırma (Tablo 6) ağırlıklarına göre; kütlenin korunumu kanununun göreli önemi bölüm içerisinde daha yüksek bulunmuştur. Bu konuyu katlı oranlar kanunu, sabit oranlar kanunu ve birleşen hacim oranları kanunu izlemektedir. 
Tablo 6 Kimyanın Temel Kanunları Bölümüne İlişsin Konuların İkili Karşılaştırma Matrisi

\begin{tabular}{lccccc}
\hline & K121 & K122 & K123 & K124 & Yerel Ă̆ırlıklar \\
\hline Kütlenin Korunuтu Kanunu (K121) & 1 & 3 & 2 & 3 & 0.4493 \\
\hline Sabit Oranlar Kапипи (K122) & & 1 & 1 & 1 & 0.1701 \\
\hline Katlı Oranlar Kanunu (K123) & & & 1 & 3 & 0.2512 \\
\hline Birleşen Hacim Oranları Kanunu (124) & & & 1 & 0.1294 \\
\hline T.O:0.04 & & & & \\
\hline
\end{tabular}

Kimyasal bağ kavramının gelişimi bölümünü oluşturan (Tablo 7) maddenin halleri ve kimyasal bağlar konusu ile kimyasal bağ ve elektriksel çekme-itme kuvvetleri ilişkisi konusunun eşit ağırlıkta bulunmuştur. Kimyasal bağın tarihsel gelişimi konusu ise düşük düzeyde bulunmuştur.

Tablo 7 Kimyasal Bağ Kavramının Gelişimi Bölümüne İlişkin Konuların İkili Karşılaştırma Matrisi

\begin{tabular}{lcccc}
\hline & K131 & K132 & K133 & Yerel Ağırlıklar \\
\hline Kimyasal Bă̆ın Tarihsel Gelişimi (K131) & 1 & $1 / 5$ & $1 / 5$ & 0.0909 \\
\hline Maddenin Halleri ve Kimyasal Bağlar (K132) & & 1 & 1 & 0.4545 \\
\hline $\begin{array}{l}\text { Kimyasal Bă̆ ve Elektriksel Çekme - İtme } \\
\text { Kuvvetleri Ilişskisi (K133) }\end{array}$ & & & 1 & 0.4545 \\
\hline T.O:0.00 & & & & \\
\hline
\end{tabular}

\section{Bileşikler Ünitesini Oluşturan Bölüm ve Konulara İlişkin İkili Karşılaştırma Matrisleri}

9. sınıf kimya dersi içeriğinde yer alan bileşikler ünitesini oluşturan dört bölümün yerel ağırlıkları (Tablo 8) incelendiğinde, bileşikler nasıl oluşur bölümünün ağırlığı diğer üç bölümün ağırlığının toplamından yüksek bulunmuştur. İyonik bileşikler ve kovalent bileşikler eşit ağırlıklı bulunmuştur. Organik bileşiklerin ünite içerisindeki ağırlı̆̆ \% 7.8 düzeyindedir.

Tablo 8 Bileşikler Ünitesine İlişkin Bölümlerin İkili Karşılaştırma Matrisi

\begin{tabular}{lccccc}
\hline & K21 & K22 & K23 & K24 & Yerel Ăğırlıklar \\
\hline Bileşikler Nasıl Oluşur? (K21) & 1 & 3 & 3 & 5 & 0.5222 \\
\hline Iyonik Bileşikler (K22) & & 1 & 1 & 3 & 0.1998 \\
\hline Kovalent Bileşikler $($ K23) & & & 1 & 3 & 0.1998 \\
\hline Organik Bileşikler $($ K24) & & & & & 0.0781 \\
\hline T.O: 0.02 & & & & \\
\hline
\end{tabular}

Bileşikler nasıl oluşur bölümüne ilişkin konuların yerel ağırlıklar (Tablo 9) incelendiğinde, elementlerin elektron alma-verme-ortaklaşma eğilimleri konusu ve iyon yükü ve yükseltgenme basamağı konusunun göreli öneminin eşit düzeyde olduğu saptanmıştır.

Tablo 9 Bileşikler Nasıl Oluşur? Bölümüne İlişkin Konuların İkili Karşılaştırma Matrisi

\begin{tabular}{lccc}
\hline & K211 & K212 & Yerel Ă̆ırlıklar \\
\hline Elementlerin Elektron alma - Verme - Ortaklaşma Ĕ̈ilimleri (K211) & 1 & 1 & 0.5000 \\
\hline İyon Yükü ve Yükseltgenme Basamă̆l (K212) & & 1 & 0.5000 \\
\hline T.O: 0.00 & & & \\
\hline
\end{tabular}


İyonik bileşikler bölümü kapsamındaki iyonlardan bileşik oluşumu konusunun göreli öneminin iyonik bileşiklerin örgü yapısına göre çok yüksek olduğu saptanmıştır (Tablo 10).

Tablo 10 İyonik Bileşikler Bölümüne İlişkin Konuların İkili Karşıllaştırma Matrisi

\begin{tabular}{|c|c|c|c|}
\hline & K221 & K222 & Yerel Ăğırlıklar \\
\hline İyonlardan Bileşik oluşumu (K221) & 1 & 5 & 0.8333 \\
\hline İyonik Bileşiklerin Örgü Yapısı (K222) & & 1 & 0.1667 \\
\hline T.O:0.00 & & & \\
\hline
\end{tabular}

Kovalent bileşikler bölümünü oluşturan kovalent bağ ve kovalent bileşiklerin oluşumu konusunun ağırlığg kovalent bağlarda polarlık konusuna göre yüksek bulunmuştur (Tablo 11).

Tablo 11 Kovalent Bileşikler Bölümüne İlişkin Konuların İkili Karşılaştırma Matrisi

\begin{tabular}{lccc}
\hline & K231 & K232 & Yerel Ă̆ırlıklar \\
\hline Kovalent Bă̆ ve Kovalent Bileşiklerin Oluşumu (K231) & 1 & 3 & 0.7500 \\
\hline Kovalent Bă̆larda Polarlık (K232) & & 1 & 0.2500 \\
\hline T.O: 0.00 & & & \\
\hline
\end{tabular}

Organik bileşikler bölümünün içerdiği konuların ağırlıkları incelendiğinde (Tablo 12), öncelikli ağırlığa sahip olan konu organik moleküllerin hidrofob ve hidrofil konularıdır. Bu konuyu polarlığın çözünmedeki rolü, hidrokarbonlar ve yaygın organik bileşikler ve organik ve anorganik bileşiklerin ayırt edilmesi konuları izlemektedir.

Tablo 12 Organik Bileşikler Bölümüne İlişkin Konuların İkili Karşılaştırma Matrisi

\begin{tabular}{|c|c|c|c|c|c|}
\hline & K241 & K242 & K243 & K244 & $\begin{array}{c}\text { Yerel } \\
\text { Ağırlıklar }\end{array}$ \\
\hline $\begin{array}{l}\text { Organik ve Anorganik Bileşiklerin Ayırt Edilmesi } \\
\text { (K241) }\end{array}$ & 1 & 1 & $1 / 3$ & $1 / 3$ & 0.1276 \\
\hline Hidrokarbonlar ve Yaygın Organik Bileşikler (K242) & & 1 & 3 & 2 & 0.1420 \\
\hline $\begin{array}{l}\text { Organik Moleküllerin Hidrofob ve Hidrofil Bölümleri } \\
\text { (K243) }\end{array}$ & & & 1 & 1 & 0.3828 \\
\hline Polarlığın Çözünmedeki Rolü (K244) & & & & 1 & 0.3475 \\
\hline T.O:0.01 & & & & & \\
\hline
\end{tabular}

Kimyasal Değişimler Ünitesini Oluşturan Bölüm ve Konulara İlişkin İkili Karşılaştırma Matrisleri

Kimyasal değişimler ünitesini oluşturan üç alt bölümün ikili karşılaştırmaları ve yerel ağırlıkları incelendiğinde (Tablo 13), tepkime nedir ile tepkime türleri bölümünün eşit ağırlıkta olduğu, polimerleşme ve hidroliz bölümünün ağırlığının ise \% 14.3 düzeyinde olduğu saptanmıştır. 
Tablo 13 Kimyasal Değişimler Ünitesine İlişkin Bölümlerin İkili Karşılaştırma Matrisi

\begin{tabular}{lcccc}
\hline & K31 & K32 & K33 & Yerel Ă̆ırlıklar \\
\hline Tepkime Nedir? (K31) & 1 & 1 & 3 & 0.4286 \\
\hline Tepkime Türleri (K32) & & 1 & 3 & 0.4286 \\
\hline Polimerleşme ve Hidroliz (K33) & & & 1 & 0.1429 \\
\hline T.O:0.00 & & & \\
\hline
\end{tabular}

Kimyasal değişimler ünitesine ilişkin bölümlerin ağırlıkları da araştırmada incelenmiştir. Buna göre tepkime nedir bölümünü (Tablo 14) oluşturan kimyasal ve fiziksel özellikler konusunun göreli ağırlığı kimyasal tepkimelerden yüksek bulunmuştur.

Tablo 14 Tepkime Nedir? Bölümüne İlişkin Konuların İkili Karşılaştırma Matrisi

\begin{tabular}{lccc}
\hline & K311 & K312 & Yerel Ă̆ırlıklar \\
\hline Kimyasal ve Fiziksel Özellikler (K311) & 1 & 3 & 0.7500 \\
\hline Kimyasal Tepkimeler (K312) & & 1 & 0.2500 \\
\hline T.O: 0.00 & & & \\
\hline
\end{tabular}

Tepkime türlerine ilişkin bölümün konularının yerel ağırlıkları incelendiğinde (Tablo 15) çözünme-çökelme tepkimeleri konusunun öncelikli bir ağırlığa sahip olduğu saptanmıştır. Bu konuyu sırasıyla asit-baz tepkimeleri ve indirgenme-yükseltgenme tepkimeleri ve yanma tepkimeleri izlemiştir.

Tablo 15 Tepkime Türleri Bölümüne İlişkin Konuların İkili Karşılaştırma Matrisi

\begin{tabular}{lccccc}
\hline & K321 & $\mathbf{K 3 2 2}$ & $\mathbf{K 3 2 3}$ & $\mathbf{K 3 2 4}$ & Yerel Ăğılıklar \\
\hline Yanma Tepkimeleri (K321) & 1 & $1 / 5$ & $1 / 5$ & $1 / 5$ & 0.0596 \\
\hline Çözünme-Çökelme Tepkimeleri (K322) & & 1 & 1 & 3 & 0.4099 \\
\hline Asit-Baz (Nötrleşme) Tepkimeleri (K323) & & & 1 & 1 & 0.2981 \\
\hline $\begin{array}{l}\text { Indirgenme - Yükseltgenme Tepkimeleri } \\
\text { (K324) }\end{array}$ & & & & 1 & 0.2324 \\
\hline T.O:0.06 & & & & \\
\hline
\end{tabular}

Polimerleşme ve hidroliz bölümünü oluşturan ikili karşılaştırma matrisi ve yerel ağırlıklara (Tablo 16) göre, her iki konunun da eşit önem düzeyinde olduğu saptanmıştır.

Tablo 16 Polimerleşme ve Hidroliz Bölümüne İlişkin Konuların İkili Karşılaştırma Matrisi

\begin{tabular}{lccc}
\hline & K331 & K332 & Yerel Ăğılıklar \\
\hline Polimerleşme (K331) & 1 & 1 & 0.5000 \\
\hline Hidroliz Tepkimeleri (K332) & & 1 & 0.5000 \\
\hline T.O:0.00 & & & \\
\hline
\end{tabular}




\section{Karışımlar Ünitesini Oluşturan Bölüm ve Konulara İlişkin İkili Karşılaştırma Matrisleri}

Karışımlar ünitesinin içerdiği bölümlere ilişkin ikili karşılaştırma matrisi ve yerel ağırlıklar (Tablo 17) incelendiğinde, karışımların sınıflandırılmasının önemli düzeyde bir ağırlığın olduğu saptanmıştır. Karışımların ayrılması bölümünün ünite içerisinde \% 12.5 düzeyinde bir ağırlığı bulunmuştur.

Tablo 17 Karışımlar Ünitesine İlişkin Bölümlerin İkili Karşılaştırma Matrisi

\begin{tabular}{lccc}
\hline & K41 & K42 & Yerel Ăgırlıklar \\
\hline Karışımların Sinıflandırılması (K41) & 1 & 7 & 0.8750 \\
\hline Karışımların Ayrılması (K42) & & 1 & 0.1250 \\
\hline T.O:0.00 & & & \\
\hline
\end{tabular}

Karışımların sınıflandırılması bölümünün içerdiği konuların yerel ağırlıklarına göre (Tablo 18), çözelti ve çözünürlük konusunun ağırlığı yüksek bulunmuştur.

Tablo 18 Karışımların Sınıflandırılması Bölümüne İlişkin Konuların İkili Karşılaştırma Matrisi

\begin{tabular}{lccc}
\hline & K411 & K412 & Yerel Ă̆ırlıklar \\
\hline Karışımlar (K411) & 1 & $1 / 7$ & 0.1250 \\
\hline Çözelti ve Çözünürlük (K412) & & 1 & 0.8750 \\
\hline T.O:0.00 & & & \\
\hline
\end{tabular}

Karışımların ayrılması bölümün oluşturan konuların yerel ağırlıklarına göre (Tablo 19), kaynama sıcaklıkları farkından yararlanılarak uygulanan ayırma yöntemlerinin ağırlığının diğer üç konunun yerel ağırlığından yüksek olduğu saptanmıştır. İkinci ağırlıklı konu çözünürlük farkından yararlanılarak kullanılan ayırma yöntemleri konusudur. $\mathrm{Bu}$ konuyu sırasıyla yoğunluk ve tanecik boyutu farkından yararlanılarak geliştirilen ayırma yöntemleri izlemektedir.

Tablo 19 Karışımların Ayrılması Bölümüne İlişkin Konuların İkili Karşılaştırma Matrisi

\begin{tabular}{lccccc}
\hline & K421 & K422 & K423 & K424 & Yerel Ă̆ırlıklar \\
\hline $\begin{array}{l}\text { Tanecik Boyutu Farkından Yararlanılarak } \\
\text { Geliştirilen Ayırma Yöntemleri (K421) }\end{array}$ & 1 & $1 / 3$ & $1 / 5$ & $1 / 7$ & 0.0521 \\
\hline $\begin{array}{l}\text { Yoğunluk Farkından Yararlanılarak Geliş̧tirilen } \\
\text { Ayırma Yöntemleri (K422) }\end{array}$ & 1 & $1 / 3$ & $1 / 5$ & 0.1090 \\
\hline $\begin{array}{l}\text { Cözünürlük Farkından Yararlanılarak } \\
\text { Kullanılan Ayırma Yöntemleri (K423) }\end{array}$ & & 1 & $1 / 5$ & 0.2195 \\
\hline $\begin{array}{l}\text { Kaynama Sicaklıkları Farkından Yaralanılarak } \\
\text { Uygulanan Ayırma Yöntemleri (K424) }\end{array}$ & & & 1 & 0.6194 \\
\hline T.O:0.09 & & & & \\
\hline
\end{tabular}


Hayatımızda Kimya Ünitesini Oluşturan Bölüm ve Konulara İlişkin İkili Karşılaştırma Matrisleri

Hayatımızda kimya ünitesini oluşturan bölümlerin göreli ağırlıklarına göre (Tablo 20), temizlik maddeleri en yüksek ağırlıkta bulunmuştur. Bu bölümü çevre kimyası, biyolojik sistemlerde kimya ve yaygın malzemeler izlemiştir.

Tablo 20 Hayatımızda Kimya Ünitesine İlişkin Bölümlerin İkili Karşılaştırma Matrisi

\begin{tabular}{lccccc}
\hline & K51 & K52 & K53 & K54 & Yerel Ă̆ırlıklar \\
\hline Temizlik Maddeleri (K51) & 1 & 5 & 3 & 1 & 0.4099 \\
\hline Yaygın Malzemeler (K52) & & 1 & $1 / 5$ & $1 / 5$ & 0.0596 \\
\hline Biyolojik Sistemlerde Kimya (K53) & & & 1 & 1 & 0.2323 \\
\hline Çevre Kimyast (K54) & & & 1 & 0.2981 \\
\hline T.O:0.06 & & & \\
\hline
\end{tabular}

Temizlik maddeleri bölümünü oluşturan konular arasında sabun ve deterjan kiri nasıl temizler konusu en yüksek ağırlıkta bulunmuştur (Tablo 21). İzleyen konular ise sırasıyla sabun ve deterjan arasındaki benzerlikler ve farklılıklar, sabun ve deterjan, çamaşır sodası, çamaşır suyu ve temizlik maddelerinin kimyası konularıdır.

Tablo 21 Temizlik Maddeleri Bölümüne İlişkin Konuların İkili Karşılaştırma Matrisi

\begin{tabular}{|c|c|c|c|c|c|c|c|}
\hline & K511 & K512 & K513 & K514 & K515 & K516 & $\begin{array}{c}\text { Yerel } \\
\text { A ğırlıklar }\end{array}$ \\
\hline Temizlik Maddelerinin Kimyası (K511) & 1 & $1 / 5$ & $1 / 7$ & $1 / 7$ & $1 / 5$ & $1 / 5$ & 0.0280 \\
\hline Sabun ve Deterjan (K512) & & 1 & $1 / 5$ & $1 / 3$ & 3 & 3 & 0.1346 \\
\hline $\begin{array}{l}\text { Sabun ve Deterjan Kiri Nasil Temizler? } \\
\text { (K513) }\end{array}$ & & & 1 & 3 & 5 & 5 & 0.4302 \\
\hline $\begin{array}{l}\text { Sabun ve Deterjan Arasindaki Benzerlikler ve } \\
\text { Farklılıklar (K514) }\end{array}$ & & & & 1 & 5 & 5 & 0.2641 \\
\hline Çamaşır sodası (K515) & & & & & 1 & 1 & 0.0716 \\
\hline Çamaşır suyu (K516) & & & & & & 1 & 0.0716 \\
\hline T.O: 0.08 & & & & & & & \\
\hline
\end{tabular}

Yaygın malzemeler bölümünün içerdiği konularının yerel ağırlıkları incelendiğinde (Tablo 22), boyalar ve bileşenler konusunun yerel ağırlığının daha yüksek olduğu saptanmıştır. Alaşımlar konusu ikinci sırada ağırlıklı bulunmuştur. Bu konuyu cam ve bileşenler, porselen ve seramik, sönmemiş ve sönmüş kireç konuları izlemektedir.

Tablo 22 Yaygın Malzemeler Bölümüne İlişkin Konuların İkili Karşılaştırma Matrisi

\begin{tabular}{lcccccc}
\hline & K521 & K522 & K523 & K524 & K525 & Yerel Ă̆ırlıklar \\
\hline Sönmemiş ve Sönmüş Kireç (K521) & 1 & $1 / 3$ & $1 / 3$ & $1 / 5$ & $1 / 7$ & 0.0483 \\
\hline Cam ve Bileşenleri (K522) & & 1 & 1 & $1 / 3$ & $1 / 3$ & 0.1166 \\
\hline Porselen ve Seramik (K523) & & & 1 & $1 / 5$ & $1 / 3$ & 0.1049 \\
\hline Boyalar ve Bileşenleri (K524) & & & & 1 & 3 & 0.4573 \\
\hline Alaşıımlar (K525) & & & & 1 & 0.2730 \\
\hline T.O: 0.05 & & & & & \\
\hline
\end{tabular}


Biyolojik sistemlerde kimya bölümünün içeriğinde yer alan konular arasında fotosentez ve solonum konusunun \% 52.8 düzeyinde ağırlıklı konu olduğu ve bunu doğal denge ve karbon dioksit, sindirim konularının izlediği saptanmıştır (Tablo 23).

Tablo 23 Biyolojik Sistemlerde Kimya Bölümüne İlişkin Konuların İkili Karşılaştırma Matrisi

\begin{tabular}{lcccc}
\hline & K531 & K532 & K533 & Yerel Ă̆ırlıklar \\
\hline Fotosentez ve Solunum (K531) & 1 & 3 & 2 & 0.5278 \\
\hline Sindirim (K532) & & 1 & $1 / 3$ & 0.1396 \\
\hline Doğal Denge ve Karbon Dioksit (K533) & & & & 0.3325 \\
\hline T.O:0.05 & & & \\
\hline
\end{tabular}

Hayatımızda kimya ünitesini oluşturan bölümlerin sonuncusu olan çevre kimyasına ilişkin ikili karşılaştırmaların yerel ağırlıklarına göre (Tablo 24), sanayi ve çevre kirliliği ile çevre endüstrisi ve enerji ilişkisi konularının eşit ağırlıkta olduğu saptanmıştır. Yine hava kirliği, su kirliliği ve toprak kirliliğinin de benzer şekilde eşit önemde oldukları belirlenmiştir.

Tablo 24 Çevre Kimyası Bölümüne İlişkin Konuların İkili Karşılaştırma Matrisi

\begin{tabular}{lcccccc}
\hline & K541 & K542 & K543 & K544 & K545 & Yerel Ă̆ırlıklar \\
\hline Sanayi ve Çevre Kirliliği (K541) & 1 & 3 & 3 & 3 & 1 & 0.3333 \\
\hline Hava Kirliliği (K542) & & 1 & 1 & 1 & $1 / 3$ & 0.1111 \\
\hline Su Kirliliği (K543) & & & 1 & 1 & $1 / 3$ & 0.1111 \\
\hline Toprak Kirliliği (K544) & & & & & 1 & 1 \\
\hline Çevre Endüstri ve Enerji Illişkisi (K545) & & & & & & 0.1111 \\
\hline T.O:0.00 & & & & & \\
\hline
\end{tabular}

\section{Kimya Ders Kitabında Yer Alan Alt Konulara İlişkin Global Ă̆ırlıklar}

Çalışmanın bu kısmında her bir konunun global ağırlıkları hesaplanmıştır. Global ağırlıklar kimya ders kitabının içermiş olduğu konuların kimya dersi konularının bütünü içerisindeki genel ağırlı̆̆ını ifade etmektedir. Global ağırlık her hangi bir konunun toplam ağırlık içinde diğer konulara göre ne düzeyde önem taşıdığını belirtmektedir. Araştırma kapsamına alınan 9. sınıf kimya dersi program ve kitabının içeriğinde yer alan toplam 53 alt konuya (Çizim 1) ilişkin hesaplanan global ağırlıklar Tablo 25'de verilmiştir. Tablo 25 incelendiğinde, global ağırlığı \% 1'den büyük olan 22 konunun 9. sinıf kimya dersi içeriğindeki toplam ağırlığının \% 90.59 düzeyinde olduğu saptanmıştır. 
Tablo 25 Alt Konulara İlişkin Global Ağırlıklar

\begin{tabular}{|c|c|}
\hline Konular & Ăğırlıklar \\
\hline Eski Çağlarda Keşfedilen Maddeler (K111) & .0008 \\
\hline Simya (K112) & .0008 \\
\hline Element Kavramının Tarihsel Gelişimi (K113) & .0025 \\
\hline Kütlenin Korunumu Kanunu (K121) & .0133 \\
\hline Sabit Oranlar Kanunu (K122) & .0050 \\
\hline Katlı Oranlar Kanunu (K123) & .0074 \\
\hline Birleşen Hacim Oranları Kanunu (124) & .0038 \\
\hline Kimyasal Bağın Tarihsel Gelişimi (K131) & .0027 \\
\hline Maddenin Halleri ve Kimyasal Bağlar (K132) & .0134 \\
\hline Kimyasal Bağ ve Elektriksel Çekme - İtme Kuvvetleri İlişkisi (K133) & .0134 \\
\hline Elementlerin Elektron alma - Verme - Ortaklaşma Eğilimleri (K211) & .1248 \\
\hline İyon Yükü ve Yükseltgenme Basamağ1 (K212) & .1248 \\
\hline İyonlardan Bileşik oluşumu (K221) & .0796 \\
\hline İyonik Bileşiklerin Örgü Yapısı (K222) & .0159 \\
\hline Kovalent Bağ ve Kovalent Bileşiklerin Oluşumu (K231) & .0716 \\
\hline Kovalent Bağlarda Polarlık (K232) & .0239 \\
\hline Organik ve Anorganik Bileşiklerin Ayırt Edilmesi (K241) & .0048 \\
\hline Hidrokarbonlar ve Yaygın Organik Bileşikler (K242) & .0053 \\
\hline Organik Moleküllerin Hidrofob ve Hidrofil Bölümleri (K243) & .0143 \\
\hline Polarlığın Çözünmedeki Rolü (K244) & .0130 \\
\hline Kimyasal ve Fiziksel Özellikler (K311) & .0851 \\
\hline Kimyasal Tepkimeler (K312) & .0284 \\
\hline Yanma Tepkimeleri (K321) & .0068 \\
\hline Çözünme - Çökelme Tepkimeleri (K322) & .0465 \\
\hline Asit - Baz (Nötrleşme) Tepkimeleri (K323) & .0338 \\
\hline İndirgenme - Yükseltgenme Tepkimeleri (K324) & .0264 \\
\hline Polimerleşme (K331) & .0189 \\
\hline Hidroliz Tepkimeleri (K332) & .0189 \\
\hline Karışımlar (K411) & .0149 \\
\hline Çözelti ve Çözünürlük (K412) & .1043 \\
\hline Tanecik Boyutu Farkından Yaralanılarak Geliştirilen Ayırma Yöntemleri (K421) & .0009 \\
\hline Yoğunluk Farkından Yaralanılarak Geliştirilen Ayırma Yöntemleri (K422) & .0019 \\
\hline Çözünürlük Farkından Yaralanılarak Kullanılan Ayırma Yöntemleri (K423) & .0037 \\
\hline Kaynama Sıcaklıkları Farkından Yaralanılarak Uygulanan Ayırma Yöntemleri (K424) & .0105 \\
\hline Temizlik Maddelerinin Kimyası (K511) & .0007 \\
\hline Sabun ve Deterjan (K512) & .0032 \\
\hline Sabun ve Deterjan Kiri Nas1l Temizler? (K513) & .0102 \\
\hline Sabun ve Deterjan Arasındaki Benzerlikler ve Farklılıklar (K514) & .0062 \\
\hline Çamaşır sodası (K515) & .0017 \\
\hline Çamaşır suyu (K516) & .0017 \\
\hline Sönmemiş ve Sönmüş Kireç (K521) & .0002 \\
\hline Cam ve Bileşenleri (K522) & .0004 \\
\hline Porselen ve Seramik (K523) & .0004 \\
\hline Boyalar ve Bileșenleri (K524) & .0016 \\
\hline Alaşımlar (K525) & .0009 \\
\hline Fotosentez ve Solunum (K531) & .0071 \\
\hline Sindirim (K532) & .0019 \\
\hline Doğal Denge ve Karbon Dioksit (K533) & .0045 \\
\hline Sanayi ve Cevre Kirliliği (K541) & .0057 \\
\hline Hava Kirliliği (K542) & .0019 \\
\hline Su Kirliliği (K543) & .0019 \\
\hline Toprak Kirliliği (K544) & .0019 \\
\hline Çevre Endüstri ve Enerji İlişkisi (K545) & .0057 \\
\hline
\end{tabular}




\section{Konulara Göre Önerilen Öğretim Yöntem ve Tekniklerinin Ă̆ırlıkları}

Çalışmanın bu kısmında 9. sınıf kimya ders kitabının bütünü ve içermiş olduğu her bir alt konu temelinde öğretim sürecinde kullanılması olası öğretim yöntem ve tekniklerinin ağırlığının ne düzeyde olduğu verilmiştir. AHP modelinde (Çizim 1) yer alan bütün konular temelinde kullanılması olası öğretim yöntemlerinin ağırlıkları incelendiğinde; anlatım \% 32, laboratuvar \% 18.9, gösteri 24.9, soru-cevap \% 15.2, proje çalışması \% 9'dur. Araştırmada aynı zamanda konular temelinde de öğretim yöntem ve tekniklerinin ağırlıkları (Tablo 26 ve Tablo 27) belirlenmiştir. Diğer bir deyişle kimya dersinin içeriğini oluşturan her bir alt konuda hangi öğretim yöntem ve tekniğinin ne düzey bir ağırlıkta kullanılabileceği belirlenmiştir. Tablonun (26 ve 27) birinci sütununda konular, diğer sütunlarda sırasıyla anlatım, laboratuvar, gösteri, soru-cevap, proje çalışması yöntemlerinin ağırlıkları yer almaktadır. Tablo 26 ve 27'de konulara, göre öğretim yöntemlerinin global ağırlıkları yer almaktadır.

Tablo 26 Alt Konulara Göre Öğretim Yöntem ve Tekniklerinin Global Ağırlıkları

\begin{tabular}{|c|c|c|c|c|c|}
\hline Konular & $\mathbf{A}$ & $\mathbf{L}$ & $\mathbf{G}$ & $\mathbf{S}$ & $\mathbf{P}$ \\
\hline Eski Çağlarda Keşfedilen Maddeler (K111) & .496 & .268 & .132 & .034 & .070 \\
\hline Simya (K112) & .455 & .042 & .068 & .151 & .284 \\
\hline Element Kavramının Tarihsel Gelişimi (K113) & .442 & .037 & .073 & .254 & .193 \\
\hline Kütlenin Korunumu Kanunu (K121) & .043 & .507 & .257 & .122 & .069 \\
\hline Sabit Oranlar Kanunu (K122) & .044 & .507 & .257 & .123 & .069 \\
\hline Katlı Oranlar Kanunu (K123) & .457 & .045 & .143 & .278 & .077 \\
\hline Birleşen Hacim Oranları Kanunu (124) & .489 & .041 & .134 & .240 & .097 \\
\hline Kimyasal Bağın Tarihsel Gelişimi (K131) & .486 & .038 & .094 & .250 & .131 \\
\hline Maddenin Halleri ve Kimyasal Bağlar (K132) & .453 & .041 & .277 & .155 & .074 \\
\hline Kimyasal Bağ ve Elektriksel Çekme - İtme Kuvvetleri İlişkisi (K133) & .449 & .042 & .277 & .143 & .090 \\
\hline Elementlerin Elektron alma - Verme - Ortaklaşma Eğilimleri (K211) & .490 & .038 & .078 & .240 & .155 \\
\hline İyon Yükü ve Yükseltgenme Basamağ1 (K212) & .460 & .033 & .276 & .168 & .063 \\
\hline İyonlardan Bileşik oluşumu (K221) & .448 & .038 & .275 & .166 & .072 \\
\hline İyonik Bileşiklerin Örgü Yapısı (K222) & .448 & .038 & .275 & .166 & .072 \\
\hline Kovalent Bağ ve Kovalent Bileşiklerin Oluşumu (K231) & .478 & .035 & .274 & .135 & .078 \\
\hline Kovalent Bağlarda Polarlık (K232) & .031 & .489 & .268 & .132 & .080 \\
\hline Organik ve Anorganik Bileşiklerin Ayırt Edilmesi (K241) & .405 & .033 & .156 & .311 & .096 \\
\hline Hidrokarbonlar ve Yaygın Organik Bileşikler (K242) & .343 & .032 & .411 & .136 & .077 \\
\hline Organik Moleküllerin Hidrofob ve Hidrofil Bölümleri (K243) & .474 & .033 & .291 & .142 & .060 \\
\hline Polarlığın Çözünmedeki Rolü (K244) & .463 & .032 & .321 & .126 & .057 \\
\hline Kimyasal ve Fiziksel Özellikler (K311) & .511 & .034 & .250 & .142 & .063 \\
\hline Kimyasal Tepkimeler (K312) & .446 & .285 & .151 & .083 & .034 \\
\hline Yanma Tepkimeleri (K321) & .029 & .504 & .259 & .071 & .137 \\
\hline Çözünme - Çökelme Tepkimeleri (K322) & .034 & .508 & .262 & .119 & .077 \\
\hline Asit - Baz (Nötrleşme) Tepkimeleri (K323) & .034 & .508 & .262 & .119 & .077 \\
\hline İndirgenme - Yükseltgenme Tepkimeleri (K324) & .034 & .508 & .262 & .119 & .077 \\
\hline Polimerleşme (K331) & .365 & .042 & .356 & .152 & .085 \\
\hline Hidroliz Tepkimeleri (K332) & .365 & .042 & .356 & .152 & .085 \\
\hline Karışımlar (K411) & .032 & .493 & .306 & .112 & .056 \\
\hline Çözelti ve Çözünürlük (K412) & .033 & .506 & .277 & .125 & .059 \\
\hline $\begin{array}{l}\text { Tanecik Boyutu Farkından Yaralanılarak Geliştirilen Ayırma } \\
\text { Yöntemleri (K421) }\end{array}$ & .041 & .453 & .277 & .074 & .155 \\
\hline
\end{tabular}


Tablo 27 Alt Konulara Göre Öğretim Yöntem ve Tekniklerinin Global Ağırlıkları

\begin{tabular}{|c|c|c|c|c|c|}
\hline Konular & $\mathbf{A}$ & $\mathbf{L}$ & $\bar{G}$ & $\bar{S}$ & $\mathbf{P}$ \\
\hline $\begin{array}{l}\text { Yoğunluk Farkından Yaralanılarak Geliştirilen Ayırma Yöntemleri } \\
\text { (K422) }\end{array}$ & .029 & .453 & .281 & .079 & .158 \\
\hline $\begin{array}{l}\text { Çözünürlük Farkından Yaralanılarak Kullanılan Ayırma Yöntemleri } \\
\text { (K423) }\end{array}$ & .038 & .464 & .273 & .073 & .153 \\
\hline $\begin{array}{l}\text { Kaynama Sıcaklıkları Farkından Yaralanılarak Uygulanan Ayırma } \\
\text { Yöntemleri (K424) }\end{array}$ & .034 & .478 & .264 & .070 & .153 \\
\hline Temizlik Maddelerinin Kimyası (K511) & .289 & .042 & .456 & .140 & .075 \\
\hline Sabun ve Deterjan (K512) & .069 & .376 & .402 & .114 & .040 \\
\hline Sabun ve Deterjan Kiri Nasıl Temizler? (K513) & .037 & .510 & .253 & .121 & .079 \\
\hline Sabun ve Deterjan Arasındaki Benzerlikler ve Farklılıklar (K514) & .442 & .037 & .073 & .254 & .193 \\
\hline Çamaşır sodası (K515) & .488 & .042 & .269 & .135 & .066 \\
\hline Çamaşır suyu (K516) & .253 & .042 & .455 & .150 & .099 \\
\hline Sönmemiş ve Sönmüş Kireç (K521) & .050 & .424 & .261 & .107 & .158 \\
\hline Cam ve Bileşenleri (K522) & .462 & .046 & .252 & .078 & .161 \\
\hline Porselen ve Seramik (K523) & .041 & .453 & .277 & .074 & .155 \\
\hline Boyalar ve Bileşenleri (K524) & .060 & .456 & .266 & .037 & .181 \\
\hline Alaşımlar (K525) & .083 & .474 & .218 & .038 & .187 \\
\hline Fotosentez ve Solunum (K531) & .064 & .115 & .426 & .036 & .359 \\
\hline Sindirim (K532) & .114 & .058 & .483 & .035 & .310 \\
\hline Doğal Denge ve Karbon Dioksit (K533) & .240 & .134 & .489 & .041 & .097 \\
\hline Sanayi ve Çevre Kirliliği (K541) & .039 & .069 & .463 & .160 & .270 \\
\hline Hava Kirliliği (K542) & .035 & .078 & .488 & .138 & .261 \\
\hline Su Kirliliğgi (K543) & .035 & .065 & .476 & .160 & .265 \\
\hline Toprak Kirliliği (K544) & .065 & .125 & .430 & .033 & .347 \\
\hline Çevre Endüstri ve Enerji İlişkisi (K545) & .070 & .119 & .343 & .044 & .423 \\
\hline
\end{tabular}

\section{Duyarlılık Analizi}

$\mathrm{Bu}$ çalışmada AHP modelinde yer alan öğretim yöntem ve tekniklerine ilişkin duyarlılık analizleri Expert Choice (2000) programı ile yapılmıştır. Duyarlılık analizinde üniteler temelinde öğretim yöntem ve tekniklerinin kullanımındaki değişimler incelenmiştir (Çizim 2). Duyarlılık analizi bulgularına göre kimyanın gelişimi (K1) ünitesinde öncelikli öğretim yönteminin anlatım (0.346) olduğu saptanmıştır. İkinci ağırlıklı öğretim yöntemi gösteri (0.226) tekniği bulunmuştur. Kimyanın gelişimi ünitesinde soru-cevap (0.170) ve laboratuvar (0.169) yöntemleri birbirine yakın ağırlıkta bulunmuştur. Kimyanın gelişimi ünitesinde olası öğretim tekniği olarak en düşük düzeyde proje yöntemi (0.088) bulunmuştur. Bileşikler (K2) ünitesinde ise yine ağırlık öğretim yönteminin anlatım (0.445) olduğu saptanmıştır. Diğer yöntemlerin bileşikler ünitesinde kullanımı sırasıyla gösteri (0.228), soru-cevap (0.178), proje çalışması (0.091) ve laboratuvar (0.057) şeklindedir. Kimyasal değişimler (K3) ünitesinde ise öncelikli öğretim yöntemi anlatım (0.285) olmakla birlikte, gösteri (0.263) ve laboratuvar (0.254) yöntemlerinin de yakın ağırlıkta oldukları saptanmıştır. Kimyasal değişimler ünitesinde en düşük ağırlıklı yöntem proje tekniği (0.071) bulunmuştur. Karışımlar (K4) ünitesi temelinde duyarlılık analizi sonuçları incelendiğinde laboratuvarın (0.500) öncelikli tercih edildiği görülmektedir. Karışımlar ünitesinde laboratuvarı sırasıyla gösteri (0.279), 
soru-cevap (0.116), proje (0.071) ve en az etkinlik gösteren anlatım (0.033) yöntemi izlemektedir. Hayatımızda kimya (K5) ünitesinde ise önceliğin gösteri (0.349) yönteminde, bunu proje (0.217), laboratuvar (0.191), anlatım (0.136) ve soru-cevap (0.107) izlemektedir. Duyarlılık analizi sonuçlarında etkin öğretim yöntem ve tekniğinin konulara göre değişim gösterdiği saptanmıştır.

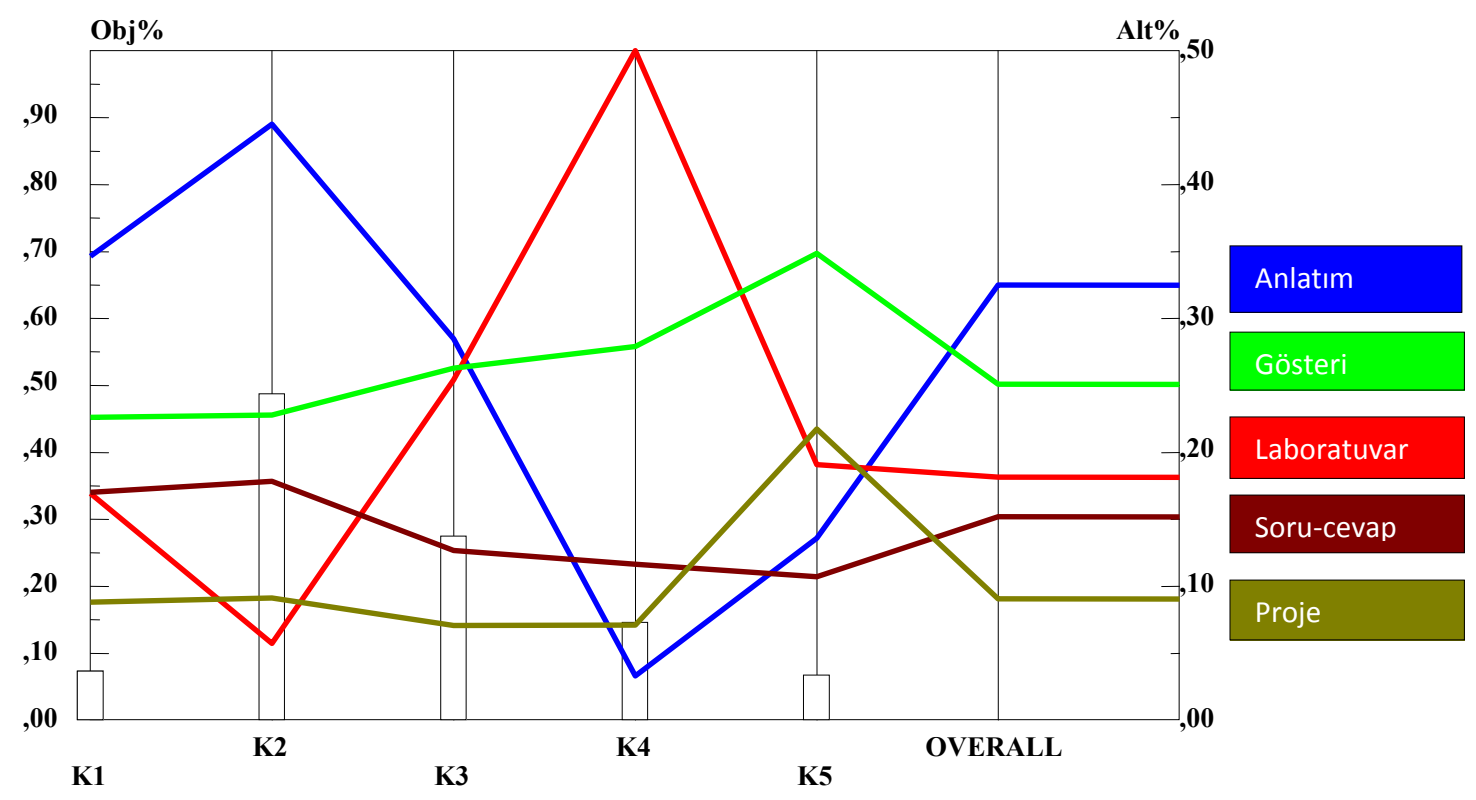

Çizim 2: Duyarlılık Analizi

\section{Sonuç ve Tartışma}

$\mathrm{Bu}$ çalışmada ortaöğretim programı 9. sınıf kimya dersi içeriğini oluşturan ünitelerin, üniteleri oluşturan bölümlerin ve bölümleri oluşturan konuların kimya dersi içerisindeki göreli ağırlıkları ve belirlenen bu ağırlıklar temelinde etkili bir kimya eğitimi için kullanılması olası öğretim yöntem ve tekniklerinin göreli ağırlıkları (önem) AHP tekniğiyle belirlenmeye çalışılmıştır.

Çalışmanın sonuçları, araştırmada kullanılan yöntem ve teknik açısından değerlendirildiğinde, AHP tekniğiyle 9. sınıf kimya dersi programı içeriğini oluşturan beş ünite, ünitelerin içerdiği 16 bölüm ve bölümlerin içermiş olduğu 53 konunun bütün kimya dersi içerisindeki göreli önem düzeylerinin belirlenebildiği görülmüştür. AHP tekniği ile kimya dersi programı içerisinde yer alan her hangi bir konunun kimya dersi içerisinde ne düzeyde bir ağırlığa sahip olduğu belirlenmekle birlikte, konuların göreli ağırlıklarının hesaplanmasına temel olan ikili karşılaştırmaların tutarlılığı da saptanmıştır. Tutarlı bir karşılaştırmanın yapılmış olması sonuçların güvenirliği açısından önemlidir. Çünkü doğaldır 
ki karşılaştırma olgusunun olduğu durumlarda belirli bir düzeyde de olsa tutarsızlık beklenebilir olmaktadır. Araştırmalarda bu durum çoğu kez ölçülememekte ya da ihmal edilmektedir. Ancak bu tutarsızlığın bulunmadığı ya da sorunsuz bir karşılaştırmanın yapıldığı anlamına gelmemektedir. Örneğin bu çalışmada ünite, bölüm ve konuların ağırlıklarının belirlenmesi için toplam 103 ikili karşılaştırma, öğretim yöntemlerinin konular temelinde ağırlıklarının belirlenmesi için 530 ikili karşılaştırma ve toplam 633 ikili karşılaştırma yapılmıştır. Bu sayıdaki bir karşılaştırmanın her hangi bir matematiksel bir teknik kullanılmaksızın yargısal ya da sezgisel bir yaklaşımla tutarlı bir şekilde yapılmasının olası olduğu söylenemez. Nitekim yapılan araştırmalarda ikili karşılaştırmalarda tutarsızlığın beklenebilir bir sorun olduğu ifade edilmektedir. Bu nedenle ikili karşılaştırmalarda tutarlılık düzeyinin belirlenmesi önemli bir konu olmakta ve buna AHP tekniği olanak sağlamaktadır (Saaty, 1994). Bu çalışmada da yapılmış olan ikili karşılaştırmaların tutarlılık düzeyleri AHP varsayımlarına göre belirlenmiş ve yapılan ikili karşılaştırmaların tutarlı olduğu saptanmıştır.

Kimya dersi programı ve kitabı içeriğinin işlevselliği ve uygulanabilirliğine yönelik yapılan çalışmalarda belirlenmiş olan sorunlar (Aydın, 2008; Aydın, 2010a; Aydın, 2010b; Kurt ve Yıldırım, 2010) farklı nedenlerden kaynaklanmakla birlikte konuların göreli önemlerinin sistematik bir yaklaşımla belirlenmemiş olmasından kaynaklandığı söylenebilir. Kimya dersi konularının göreli önemlerinin analitik bir yaklaşımla belirlenmesi öğretim programının tasarımı, uygulanması ve değerlendirilmesi bakımından önemlidir. Öznel değerlendirme ve karar verme yaklaşımından uzak nesnel bir yaklaşımla konuların göreli önemlerinin belirlenmesi program amaçlarının gerçekleştirilmesine olanak sağlayacaktır. Ancak Milli Eğitim Bakanlığının 1930-2007 yılları arasında yapmış olduğu 11 ortaöğretim kimya dersi programında (Aydın, 2010b) içeriği oluşturan konuların seçiminin ve kimya dersi içerisindeki göreli önemlerinin nasıl belirlendiği konusunda bir bilgiye rastlanılmamıştır. Bununla birlikte program içeriğinin öğrenciye kazandırılmasında hangi öğretim yöntem ve tekniklerin kullanılmasının eğitimin etkililiği açısından önemli olabileceği konusunda da bilgilendirmenin yapılmadığı görülmektedir. Yazında yer alan çalışmaların (Aydın, 2008; Kayatürk vd., 1995; Küçük vd., 2002) bulguları öğretmenlerin bu sorunla da önemli bir düzeyde karşılaştıkları saptanmıştır. Öğretmenlerin kendi bilgi ve deneyimleri temelinde, okullarındaki araç ve gereç olanakları ve donanımları çerçevesinde öğretim programlarının içermiş olduğu konuları öğrencilere kazandırmaya çalıştıkları görülmüştür. Oysaki kimya dersi programının içeriğini oluşturan konuların eğitiminin hangi öğretim yöntem ve teknikleriyle yapılabileceğinin bilinmesi kimya dersi eğitiminin etkililiği için önemlidir. 
Kimya dersinde etkili bir öğrenme için işlevsel ve uygulanabilir olabilecek öğretim yöntem ve tekniklerinin belirlenmesi sorunsalı da bütüncül, sistematik ve analitik bir yaklaşımı zorunlu kılmaktadır. Kimya dersinin içermiş olduğu konu sayısı ve çeşitliliğinden dolayı eğitimin tek bir öğretim yöntemiyle verilmesi olası değildir. Bununla birlikte etkili bir öğretim için kimya dersi içeriğindeki her hangi bir konu aynı zamanda birden fazla öğretim yöntem ve tekniğini zorunlu kılabilir ya da kullanılması durumunda daha başarılı bir sonuç oluşturabilir. Bu nedenle kimya ders içeriğinin olası hangi öğretim yöntem ve teknikleriyle verilebileceğinin belirlenmesi ve bunların öğretmenler tarafından biliniyor olması gerekmektedir. Bu çalışmanın sonucunda kimya dersi programının içermiş olduğu konuların hangi öğretim yöntem ve teknikleriyle verilebileceğinin nesnel ve bütüncül bir yaklaşımla AHP tekniğiyle belirlenebileceği görülmüştür. Nitekim bu çalışmanın kapsamında yer alan 9. sınıf kimya dersi programının konularının genelinde anlatım tekniğinin \% 32, gösteri yönteminin \% 24.9, laboratuvar \% 18.9, soru-cevap yöntemi \% 15.2 ve proje çalışması \% 9 düzeyinde kullanılabilir olduğu görülmüştür. $\mathrm{Bu}$ ağırlıklar bütün kimya dersi konuları geneline yönelik değerlerdir. Araştırmanın bulgularında görüleceği gibi her bir ünite, bölüm ve konular temelinde (Tablo 26 ve Tablo 27) de hangi yöntem ve tekniklerin kullanılabileceği belirlenmiştir.

\section{Öneriler}

$\mathrm{Bu}$ araştırmada 9. sınıf kimya dersi konularının ağırlıklarının belirlenmesi ve bu ağırlıklar temelinde konuların öğretiminde kullanılması olası öğretim yöntem ve tekniklerinin belirlenmesine ilişkin modelin diğer bilim alanlarında verilen derslerin içeriğinin ağırlıklarının ve bu derslerde kullanılması olası öğretim yöntemlerinin seçimine uyarlanabilmesi olasıdır. Araştırmanın temel almış olduğu bütüncül ve analitik AHP yaklaşımının diğer bilim alanlarına konu olan programlar için yöntem açısından genellenebilir olmasına karşılık, çalışmanın sonuçları ancak araştırmanın kapsamını oluşturan 9. sınıf kimya dersi program içeriği ile sınırlıdır. Bununla birlikte yine araştırmanın sonuçlarını 9. sınıf kimya dersi programı için genellemek olası değildir. Bunun temel nedeni araştırmanın bulgularına girdi olan veri kaynağının sınırlı bir uzman gruptan sağlanmış olmasıdır. Genellenebilir bir sonuç araştırma verilerin geniş katılımlı olan bir öğretmen ve program uzmanlarından sağlanabilmesiyle olasıdır.

$\mathrm{Bu}$ çalışmada önerilen AHP modelinde konuların birbirinden ayrık ve bağımsız olduğu varsayılmıştır. $\mathrm{Bu}$ durum araştırmada kullanılan AHP tekniğinin kuramsal temellerinden 
kaynaklanmaktadır. Ancak araştırma konusu edilen 9. sınıf kimya dersi program içeriğini oluşturan bütün konular için bu varsayımın genellenmesi olası değildir. Dolayısıyla kimya dersi programının içermiş olduğu konuların birbiriyle olan bağlantısını dikkate alan bir yaklaşımla modellenmesinin daha açıklayıcı sonuçlar sağlayabileceği söylenebilir. Bundan sonraki çalışmalarda konunun bu yönüyle irdelenmesi, modellenmesi ve çözümlenmesi önerilebilecek bir araştırmadır.

\section{Kaynakça}

Aydın, A. (2008). Ortaöğretim Öğretmenlerinin 1992'den Beri Uygulanan Ortaöğretim Kimya Müfredatları Hakkındaki Görüşleri. Eğitim ve Bilim, 33(148), 87-99.

Aydın, A. (2010a). Kimya I Ders Kitabının Öğretmen Görüşlerine Göre Değerlendirilmesi. Ahi Evran Üniversitesi Eğitim Fakültesi Dergisi, 11(1), 207-224.

Aydın, A. (2010b). Cumhuriyet Dönemi Ortaöğretim Kimya Öğretim Programlarının Esnek Program ve Uygulamaları Açsından Değerlendirilmesi. BAU Fen Bil. Enst. Dergisi $12(2), 61-74$.

Aydoğdu, C. (2003). Kimya Eğitiminde Yapılandırmacı Metoda Dayalı Laboratuvar İle Doğrulama Metoduna Dayalı Laboratuvar Eğitiminin Öğrenci Başarısı Bakımından Karşılaştırılması. Hacettepe Üniversitesi Eğitim Fakültesi Dergisi, 25, 14-18.

Bolte, C. (2008). A Conceptual Framework for the Enhancement of Popularity and Relevance of Science Education for Scientific Literacy, based on Stakeholders' Views by Means of a Curricular Delphi Study in Chemistry. Science Education International, 19(3), 331-350.

Çevik, E. ve Yücel, A.S.(2009). Bilgisayar Destekli Kimya Öğretimi İle İlgili Öğrenci Görüşleri. e-Journal of New World Sciences Academy, 4(4), 1355-1366.

Demircioğlu, H., Demircioğlu, G. ve Ayas, A. (2006). Hikayeler ve Kimya Öğretimi. H. $\ddot{U}$. Eğitim Fakültesi Dergisi, 30, 110-119.

Dursun, M.F., Gülbay, İ., Çetin, S. ve Tek, Ü. (2011). Ortaöğretim 9. Sinıf Kimya Ders Kitabı. Ankara: MEB Devlet Kitapları.

Driel, J.H.V., Bulte, A.M.W., \& Verloop, N. (2008). Using the curriculum emphasis concept to investigate teachers' curricular beliefs in the context of education reform. Journal of Curriculum Studies, 40(1), 107-122.

Ercan, O. (2011). Kimya Dersi Yeni Öğretim Programının Uygulanmasına İlişkin Öğretmen Görüşleri. Türk Fen Eğitimi Dergisi, 8(4), 193-209. 
Erdem, A.R.(2005). Öğrenmede Etkili Yollar: Öğrenme Stratejileri ve Öğretimi. İlköğretimOnline, 4(1), 1-6.

Eş, H. ve Sarıkaya, M. (2010). Türkiye ve İrlanda Fen Öğretimi Programlarının Karş1laştırılması. İlköğretim Online, 9(3), 1092-1105.

Expert Choice. (2000). Expert Choice, Analytical Hierarchy Process (AHP) Software, Version 9.5, Expert Choice, Pittsburg, USA.

Feyzioğlu, B. (2009). An Investigation of the Relationship between Science Process Skills with Efficient Laboratory Use and Science Achievement in Chemistry Education. Türk Fen Eğitimi Dergisi, 6(3), 114-132.

Gerengi, H. (2009). Kimya Öğretiminin Değerlendirilmesi. e-Journal of New World Sciences Academy Education Sciences, 4(2), 346-356.

Gültaş, İ. (2007). Endüstri Mühendisliği Ĕgitiminde Matematik Ders İçeriklerinin Belirlenmesine Bulanık AHP Yöntemi İle Çözüm Önerisi. Yayınlanmamış Yüksek Lisans Tezi. İstanbul Teknik Üniversitesi Fen Bilimleri Enstitüsü, İstanbul.

Kalem, S. ve Fer, S. (2003). Aktif Öğrenme Modeliyle Oluşturulan Öğrenme Ortamının Öğrenme, Öğretme ve İletişim Sürecine Etkisi. Kuram ve Uygulamada Eğitim Bilimleri, 3(2), 433-461.

Kayatürk, N., Geban, Ö. ve Önal, A. (1995). Genel Lise Programında Yer Alan Kimya Konularıyla İlgili Derslerin Müfredatlarının İncelenmesi Ve Ders Geçme Sisteminin Değerlendirilmesi. Hacettepe Üniversitesi Eğitim Fakültesi Dergisi, 11, 9-13.

Kurt, S. ve Yıldırım, N. (2010). Ortaöğretim 9.Sınıf Kimya Dersi Öğretim Programının Uygulanması İle İlgili Öğretmenlerin Görüşleri ve Önerileri. Ondokuz Mayıs Üniversitesi Ĕ̈itim Fakültesi Dergisi, 29(1), 91-104.

Küçük, M.M., Yetim, M., Saka, C. ve Genel, Y. (2002). Kimya Eğitim ve Öğretiminde Uygulanan Öğretim Yöntemleri Etkin Kavram Öğretimi Arasındaki İlişkinin Incelenmesi. ODTÜ, Ankara: V. Ulusal Fen Bilimleri ve Matematik Eğitimi Kongresi. Lang, Q.C., Wong, A.F.L., Fraser, B. (2005). Student Perceptions of Chemistry Laboratory Learning Environments, Student-Teacher Interactions and Attitudes in Secondary School Gifted Education Classes in Singapore. Research in Science Education, 35, 299-321.

Milli Eğitim Bakanlığı.(2007).Ortä̈ğretim 9. Sınıf Kimya Dersi Öğretim Programı. Ankara: Talim ve Terbiye Kurulu Başkanlığı. 19 Eylül 2011 tarihinde http://ttkb.meb.gov.tr/program.aspx?islem=1\&kno=172 adresinden alınmıştır. 
Morgil, İ., Yılmaz, A. ve Yavuz, S. (2002). Kimya Eğitiminde İstasyonlarda Öğrenme Modeli. Hacettepe Üniversitesi Ĕ̈itim Fakültesi Dergisi, 22, 110-117.

Morgil, İ., Erdem, E. ve Yılmaz, A. (2003). Kimya Eğitiminde Kavram Yanılgıları. Hacettepe Üniversitesi Eğitim Fakültesi Dergisi, 25, 246-255.

Pekdağ, B. (2010). Kimya Öğreniminde Alternatif Yollar: Animasyon, Simülasyon, Video ve Multimedya İle Öğrenme. Türk Fen Eğitimi Dergisi, 7(2), 79-110.

Özden, M. (2007). Kimya Öğretmenlerinin Kimya Öğretiminde Karşılaştıkları Sorunların Nitel ve Nicel Değerlendirilmesi: Adıyaman ve Malatya İlleri Örneği. Pamukkale Üniversitesi Eğitim Fakültesi Dergisi, 2(22), 40-53

Saaty, T.L. (1980). The Analytic Hierarchy Process. New York: McGraw-Hill International Book Company.

Saaty, TL. (1986). Axiomatic Foundation of the Analytic Hierarchy Process. Management Science, 32(7), 841-855.

Saaty, T.L. (1991). Some Mathematical Concepts of the Analytic Hierarchy Process. Behaviormetrika, 29, 1-9.

Saaty, T.L.(1994). How to make a decision: the analytic hierarchy process. Interfaces, 24(6), $19-43$.

Seven, M.A. ve Engin, A.O.(2008). Öğrenmeyi Etkileyen Faktörler. Atatürk Üniversitesi Sosyal Bilimler Enstitüsü Dergisi, 12(2), 189-212.

Tezcan, H. ve Günay, S. (2006). Lise Kimya Öğretiminde Laboratuvar Kullanımına İlişkin Öğrenci Görüşleri. Türk Ĕ̆itim Bilimler Dergisi, 4(1), 31-43.

Yetim, S. (2004). Tek Değişkenli Reel Değerli Fonksiyonlarda Türev Kavramına Etki Eden Bazı Matematik Kavramlarının Analitik Hiyerarşi Prosesi İle Analizi. Kastamonu Eğitim Dergisi, 12(1), 137-156. 